\title{
PORTO NOVO - A TERRA DO FUTURO
}

\section{BALDUINO RAMBO}

\section{RESUMO}

O texto do Diário de Balduíno Rambo relativo à sua viagem ao extremo oeste do estado de Santa Catarina é aqui publicado, pela primeira vez.

Palavras-chave: Balduíno Rambo, Colonização, Itapiranga, Santa Catarina.

\section{ABSTRACT}

[Porto Novo - The land of future].

The text of Balduino Rambo's Diary about his trip to the far west of Santa Catarina state (Brazil) is published here, for the first time.

Key words: Balduíno Rambo, Settlement, Itapiranga, Santa Catarina State, Brazil.

\section{APRESENTAÇÃO ${ }^{1}$}

A colonização do extremo oeste de Santa Catarina se insere e deve ser analisada em meio a um contexto histórico mais amplo. Em 1899, as lideranças coloniais alemãs católicas fundaram a "Associação Riograndense de Agricultores" - o "Bauernverein" -, juntamente com os protestantes, italianos e poloneses, tendo como estrategista maior o padre jesuíta Theodor Amstad. Tratava-se, em resumo, de um ambicioso projeto de promoção humana, interétnico e interconfessional, que se propunha por em andamento ações capazes de enfrentar os desafios que a dinâmica colonial vinha apresentando. Previa, entre outros objetivos: a modernização e diversificação da agricultura familiar; a criação de cooperativas de crédito, produção e consumo; a criação de uma política de saúde e assistência médica; o aperfeiçoamento e ampliação das redes de escolas de comunidade, somada à qualificação dos professores; a promoção de centros e associações destinadas ao lazer e à arte; implantação de projetos de seguridade social privada, etc. Entre os maiores desafios, entretanto, figurava a permanente escassez de

\footnotetext{
${ }^{1}$ A introdução é da autoria de Arthur Blasio Rambo, professor emérito da UFRGS e da UNISINOS, pesquisador do Memorial Jesuíta (UNISINOS, São leopoldo RS) e irmão de Balduíno Rambo.
}

terras para jovens agricultores oriundos de famílias numerosas.

De acordo com estudos feitos pelo Pe. Amstad, no começo do século XX acumulavamse 300 excedentes nas comunidades coloniais, em média, para cada 1000 famílias. Em idade de casar e se estabelecer em lote próprio, esses jovens dificilmente encontravam terras adequadas na região colonial mais antiga. $\mathrm{Na}$ assembléia de 1900, a "Associação dos Agricultores" resolveu enfrentar o problema com ousadia e coragem. O resultado foi a colonização de Serro Azul (Cerro Largo), Santo Cristo e arredores, no noroeste do Estado. Cerro Largo festejou o seu centenário em 2002. Essa colonização, de comum acordo entre protestantes, católicos e italianos, adotou o critério da identificação étnica e confessional na formação das comunidades. $\mathrm{O}$ argumento que resultou nesse consenso tinha, certamente, o seu valor para as circunstâncias de cem anos passados. Importava garantir as melhores condições para que as novas comunidades se consolidassem o mais rápido possível. E os dois pressupostos que naquela época realmente pesavam eram a identificação pela confissão religiosa e/ou pela identificação étnica, já que a língua alemã, italiana, polonesa era veículo de comunicação exclusiva e o pertencimento à mesma confissão religiosa sempre foi um poderoso fator de coesão 
comunal. Discutível ou não, essa estratégia parece ter sido um fator importante, senão decisivo, na consolidação e no sucesso dessa colonização.

Por decisão da assembléia geral de 1909, em Taquara, a Associação dos Agricultores foi transformada em sindicato. Para os fundadores da Associação, em 1899, tanto católicos, quanto protestantes, a ideia original do projeto estava viciado na sua essência. A idéia da interetnicidade e interconfessionalidade foi infelizmente abandonada e cada qual partiu para a sua própria associação. Os italianos fundaram os seus "Comitati", os protestantes a "Liga União Colonial" e os católicos a "Sociedade União Popular", inspiradas nas congêneres da Alemanha, Suíça e Áustria. Os "Comitati” foram poderosos promotores do cooperativismo, a "Liga União Colonial" esteve à frente de novas colonizações no Alto Uruguai e a "Sociedade União Popular", com os padres Amstad, Lassberg, Rick e Murmann, mais as lideranças leigas, levou adiante, em grandes linhas, as iniciativas já começadas e postas em andamento pela "Associação dos Agricultores". As mais vistosas concentraram-se na área da saúde e assistência social, com a implantação da "Colônia para Leprosos" em Itapuã, o asilo e hospital em Caí e a escola de formação de parteiras em Estrela. A educação foi contemplada com a fundação da Escola Normal para a formação de professores, também em Estrela. Mas o que mais preocupava era a crescente demanda de terras virgens por parte dos jovens agricultores, terras em abundância e de boa qualidade para construírem suas vidas. Depois de uma série de tentativas frustradas na margem riograndense do Alto Uruguai, veio a oferta, por parte da "Empresa Chapecó Peperi Ltda.", de terras no canto do extremo oeste de Santa Catarina, à margem direita do rio Uruguai.

Em Janeiro de 1926, numa reunião da Diretoria da Sociedade União Popular acontecida em Santa Cruz, foi acertada com Hermann Faulhaber, diretor da "Peperi-Chapecó", a compra dos primeiros cem lotes da nova coloniza- ção, no local conhecido como "Porto Novo". Na mesa de negociação encontrava-se o Pe. Johannes Rick, na condição de secretário geral da Sociedade União Popular, figura-chave na posterior implantação e consolidação do empreendimento. Maiores detalhes da história desta colonização podem ser encontrados em "Somando forças - O projeto social dos jesuítas no sul do Brasil", de Arthur Rambo (São Leopoldo: Editora Unisinos, 2011).

$\mathrm{Na}$ data em que aconteceu a assinatura do contrato que marcou o começo da colonização de Porto Novo, 26 de Janeiro de 1926, o Pe. Rambo era um jovem estudante jesuíta de 26 anos de idade, que cursava Filosofia em Pullach, perto de Munique, na Alemanha. Após sua volta ao Brasil, ele deve ter ouvido seu grande amigo e mestre, Pe. Rick, falando sobre aquele mundo encantado de florestas em vias de abrigar uma nova geração de colonos procedentes das regiões mais antigas do Rio Grande do Sul, do leste catarinense e, em número considerável, até mesmo da Alemanha. Quando criança, seu "brinquedo predileto" foram árvores da floresta, perto da casa dos pais, derivando daí, provavelmente, o desejo de conhecer "in loco" aquele cenário intacto, onde "a penumbra dos gigantes ensina muito mais do que está escrito nos livros". Nas férias, antes de começar o ano letivo de Teologia, em São Leopoldo, aproveitou o tempo disponível para degustar e viver intensamente as emoções de uma natureza praticamente intocada, compartilhando a vida de acampamento com agrimensores, caçadores de onças e mateiros, nos postos mais avançados, em lugares nunca perturbados pela civilização.

A paisagem, hoje inteiramente humanizada, progressista e de uma qualidade de vida invejável, confirma em todos os sentidos o sugestivo título escolhido por Rambo para o registro de seus apontamentos e reflexões: "Porto Novo, das Land der Zukunft - Porto Novo, a terra do futuro".

Ao leitor, resta informar que as notas de rodapé que enriquecem o texto de Balduíno Rambo foram escritas por Arthur Blasio Rambo 


\section{(ABR) e José Newton Cardoso Marchiori (JNCM).}

\section{TEXTO DE BALDUINO RAMBO}

Quando no dia nove de fevereiro o carro estacionou na frente da igreja de Itapiranga ${ }^{2}$, subi com a minha mala até a casa paroquial. Encontrei o Pe. Pio ${ }^{3}$ com seu guarda-pó branco na porta e o irmão Rabuske ${ }^{4}$ acabava de sair da adega, onde os besouros da madeira tinham começado a furar as pipas. Depois apareceu o Pe. Vosskühler $^{5}$, exatamente tão branco como o conhecera há 20 anos, em Pareci. O perfume

2 Do tupi: itá (pedra) e piranga (vermelha). Atual cidade de mesmo nome, no extremo oeste de Santa Catarina, à margem direita do rio Uruguai, distante $800 \mathrm{~km}$ da capital (Florianópolis). Sua origem deve-se à iniciativa dos dirigentes da Sociedade União Popular de criar um núcleo de colonização para católicos de origem alemã, na década de 1920. Os desbravadores, chefiados pelo Pe. Max Von Lassberg, chegaram a Porto Novo depois de percorrer $150 \mathrm{~km}$ em canoas, navegando pelos rios da Várzea e Uruguai. Emancipada de Chapecó, em 30-121953, o atual município tem área de $286,16 \mathrm{~km}^{2} \mathrm{e}$, em 2007, a sua população era estimada em 13.432 habitantes (JNCM).

3 Jesuíta suíço, o Pe. Pio Buck viveu, lecionou e pesquisou toda a vida no Colégio Anchieta, à rua Duque de Caxias, em Porto Alegre. Especialista em Himenópteros, ele reuniu uma coleção significativa, conservada no Museu do Anchieta. Ocupava um espaço no mesmo sótão, junto ao Pe. Rambo, acima da capela dos alunos do colégio. Em Porto Alegre se tornou conhecido pelo trabalho pastoral junto aos presos do antigo cadeião da Ponta do Gasômetro. De idade avançada, não acompanhou a transferência do Presídio Central para o bairro Partenon. Pelo prestígio e confiança de que gozava junto aos apenados, costumava ser chamado para intermediar negociações entre os presos e a polícia, em momentos de tensão (ABR).

4 Irmão leigo jesuíta, irmão dos padres Bruno e Arthur Rabuske, este último o maior estudioso e melhor conhecedor da obra do Pe. Rambo (ABR).

5 Pe. Ernesto Vosskülhler. Nascido na Vestfália (Alemanha), veio ao Brasil em 1887. Lecionou no Colégio Nossa Senhora da Conceição, em São Leopoldo, no Colégio Anchieta (Porto Alegre) e no Catarinense (Florianópolis). Trabalhou, também, na pastoral paroquial. De acordo com a referência do Pe. Rambo, ele se encontrava em Itapiranga na condição de coadjutor da paróquia. Faleceu em São Leopoldo, em 1940 (ABR). forte exalado pela madeira nova de louro $^{6} \mathrm{e}$ cabriúva $^{7}$ fluía de todos os cômodos e, na mesa, foi servida uma melancia como há 11 anos não degustava.

Uma breve descrição da casa construída na encosta. Por isso foi preciso enterrá-la levemente nos fundos e, na frente, apoiá-la sobre grandes blocos de pedra. As paredes são de tijolos, o telhado de tabuinhas ${ }^{8} \mathrm{e}$ as instalações internas das melhores madeiras de lei. Um corredor estreito corre pelo centro e em ambos os lados se alinham quatro quartos espaçosos. Nos fundos, uma larga passagem converge para o corredor principal, separando a cozinha e o refeitório da moradia. De lá sobe a escada que leva para o sótão. Nele dormem os meninos ${ }^{9}$ que trabalham na casa. Da janela da frente desfruta-se um magnífico panorama da cidadezinha de Itapiranga sobre o rio Uruguai, que domina a paisagem, e sobre as elevações do lado riograndense.

Quem sobe para a casa paroquial tem, a 30 metros à sua direita, a igreja, num plano um pouco mais baixo. A plantação de milho avança até as janelas. A construção é toda de madeira, o telhado de tabuinhas, encimado por uma torreta. Entrando e levantando-se a cabeça, o olhar se perde no meio de um emaranhado de traves e escoras que sobe até o telhado. Nos postes é possível contar, um por um, os golpes

${ }^{6}$ Cordia trichotoma (Vell.) Arráb. ex Steud. (Boraginaceae), madeira nobre e de cheiro característico (JNCM).

7 Myrocarpus frondosus Allemão (Fabaceae), madeira nobre, fácil de trabalhar e de cheiro característico (JNCM).

8 As tabuinhas ou "telhas de madeira" eram obtidas cortando-se troncos de árvore em cepos de meio metro e, com o auxílio de uma cunha de ferro de dimensões mais ou menos iguais e de uma marreta de madeira, rachavam-se os cepos em "telhas", empregadas na cobertura de casas e benfeitorias, em frentes de colonização na mata virgem (ABR).

9 Referência aos meninos, filhos de colonos, que costumavam encarregar-se das tarefas domésticas das casas paroquiais. Moravam na casa e, num turno, costumavam frequientar a escola (ABR). 
da serra manejada pelos punhos rudes dos serradores. No altar, São Canísio, a primeira igreja paroquial com seu nome na América do Sul.

Um domingo destes na colônia é capaz de penetrar até as raízes. Em volta da igreja escuta-se a melodia do velho e não deturpado dialeto do Hunsrück. São, antes de mais nada, os velhos cantos do hinário de $\operatorname{Trier}^{10}$ que pela primeira vez fizeram ecoar o tesouro da fé católica em nossos corações. O grande amor à fé, a fidelidade à identidade étnica e à língua materna aprendida na infância, despertam um mundo maravilhoso e meio esquecido.

Agradáveis eram as conversas no recreio, ao entardecer. Milhares de besouros de todas as espécies ajuntavam-se em volta da lâmpada. Porto Novo ${ }^{11}$ já dispõe de luz elétrica. É verdade que ainda treme, mas, certamente, aprenderá a iluminar quando ficar mais velha. Não poucas vezes o Pe. Pio saltava em pé no meio da conversa, agarrava a rede que mantinha perto de si e a agitava sobre as nossas cabeças, até que a caça caía no saco. De vez em quando aparecia um grande sapo marrom-amarelado, acomodava-se no meio da roda e com os seus grandes olhos espreitava os insetos perto da luz. Era maravilhoso observar como jogava a língua para frente e apanhava formigas e larvas. Também não recusava besouros de tamanho médio e os engolia com brutal naturalidade.

Depois, o Pe. Treis ${ }^{12}$ contou das suas andanças que se estendem sobre todo o território, até as colônias italianas ao norte, em Porto Fe-

${ }^{10}$ Uma percentagem elevada dos colonizadores de Porto Novo era de descendentes de imigrantes oriundos da diocese de Trier ou Tréveris. O uso do livro de cantos e orações oficial da diocese tinha um significado simbólico muito forte. O seu uso nas celebrações religiosas significava quase como uma renovada declaração de amor e de fidelidade às raízes (ABR).

${ }^{11}$ Nome pelo qual Itapiranga era conhecida até 10 de abril de 1926 (JNCM).

${ }^{12} \mathrm{O}$ Pe. Treis pertenceu à primeira geração de jesuítas, filhos de colonos nascidos no Brasil. Na época, era pároco de Itapiranga, uma freguesia de tamanho fora do comum, comparada às paróquias de hoje (ABR). liz $^{13}$. Desvela-se diante de nós todo o romantismo e o fardo do trabalho da velha guarda ${ }^{14}$.

Em seguida o Pe. Vosskühler recorda fatos da então província alemã que para nós, os herdeiros, se perdem no tempo e soam quase inverossímeis. E para arrematar, o Uruguai marulhava a mesma canção que um dia entoou para Roque Gonzalez. Sobre os morros do lado riograndense brilha o Cruzeiro do Sul.

\section{Viagem de coleta}

Antes de abrir este capítulo, preciso viajar de volta a Santa Bárbara ${ }^{15}$. Acontece que as coisas se ajeitaram de molde a me encontrar no mesmo hotel com o provincial que retornava de Porto Novo. Ele me apresentou ao sr. Rhode, diretor da Colônia, que também se achava presente no hotel. Deixou perceber que ele se empenhasse para que eu tomasse algum contato com a região. A forma generosa com que o sr. Rhode entendeu o "algum" é testemunha de tudo o que vou contar daqui para frente.

Vou narrar agora como eu vi as nossas terras em Porto Novo (aquelas que são propriedade da Província Sulbrasileira da Companhia de Jesus) ${ }^{16}$. Para dar conta desta tarefa precisei de dois dias, já que estas terras se localizam em dois pontos distantes entre si.

O sr. Rhode me buscou no dia 21 de fevereiro à tarde. Pela segunda vez pernoitei nos Schöler ${ }^{17}$. Na manhã do dia seguinte, depois do

${ }^{13}$ Atual Mondaí (ABR).

${ }^{14}$ É do Pe. Rambo a autoria do termo "Velha Guarda". Cunhou-o para designar os jesuítas alemães, fundadores e consolidadores da Missão no sul do Brasil. Os últimos faleceram na década de 1950 (ABR).

${ }^{15}$ Atual Santa Bárbara do Sul, cidade e município do Planalto Médio do Rio Grande do Sul. Provida de estação da estrada-de-ferro, Santa Bárbara era o núcleo de partida para os que se dirigiam ao extremo oeste de Santa Catarina (JNCM).

${ }^{16} \mathrm{O}$ Pe. Rambo refere-se a dois conjuntos de colônias adquiridas pelos jesuítas, um na Sede Capela e outro no interior de Porto Novo (ABR).

${ }^{17}$ Schöler era dono da primeira casa de comércio e hotel, onde se hospedavam os viajantes que atravessavam o rio Uruguai de balsa, vindos de Frederico Westphalen, na época conhecido como "Barril"(ABR). 
café, trouxeram dois cavalos. Num deles montou o velho Schöler, no outro eu mesmo. No caminho associou-se a nós o sr. Ruschel, o homem encarregado de mostrar as terras desta parte da Colônia. Contornamos o morro da $\mathrm{Ca}$ pela em direção ao Uruguai. A mandioca, o milho e também a erva daninha cresciam magnificamente. Picão ${ }^{18}$ e milhã ${ }^{19}$ crescem em abundância. Falta o dente-de-leão ${ }^{20}$. Em toda a parte destacam-se as flores brancas da batatasilvestre $^{21}$, tão parecida com as cultivadas que poderia ser a espécie que lhes deu origem.

Chegamos ao Uruguai, aqui excepcionalmente largo, permeado de arbustos, ao ponto de se ter a impressão de ser possível passá-lo a vau. Bem à nossa frente jaz um enorme bloco de basalto, bem no meio do rio. Não poucas balsas de madeiras nobres foram nele destroçadas. Apesar de as enchentes o cobrirem, crescem sobre ele arbustos e até um limoeiro. Ruschel contou como certa noite adormeceu enquanto pescava e, de repente, escutou algo grunhindo e esgaravatando. Quando apalpou atrás de si, meteu a mão no pelego de uma capivara que, assustada, jogou-se no rio.

Alcançamos a primeira das oito colônias que a província comprou no "Morro da Capela". Examinei detalhadamente a região. Primeiro as terras sobem uma encosta íngreme a partir do rio. Ficam depois quase inteiramente planas para, finalmente, aproximar-se suavemente do plano sobre o morro de 350 metros. Um magnífico pedaço de chão, ainda mais que no alto há água em abundância.

Passados dez minutos foi possível apreciar, através do mato, as mais memoráveis corredeiras de rio que jamais tinha visto em toda a minha

\footnotetext{
${ }^{18}$ Bidens pilosa L. (Asteraceae), erva daninha comum em roçados e lavouras (JNCM).

${ }^{19}$ Digitaria sanguinalis (L.) Scop. (Poaceae), muito provavelmente (JNCM).

${ }^{20}$ Taraxacum officinale G. Weber ex F.H. Wigg., Asteraceae ruderal (JNCM).

${ }^{21}$ Solanum commersonii Dunal (Solanaceae), espécie nativa (JNCM).
}

vida. A massa principal da água desce primeiro pelo lado riograndense, dirige-se então, mais ou menos pela diagonal, em direção à margem catarinense. Desce por uma série de degraus de basalto e cai num canal perto da margem. Vejo o escolástico (jovem estudante) do futuro para quem o Uruguai canta o hino de ninar para as teses $^{22}$.

Tinha ouvido falar que no lado riograndense havia uma fonte sulfurosa e para ela encaminhei intencionalmente a conversa. Cavalgamos até um morador lá em baixo, perto do rio. Era um homem enorme, cabelos louros e rosto maltratado pelas intempéries. Quando embarcamos na canoa seus seis filhos enfileiraram-se no barranco como os tubos de um órgão, enquanto a mulher observava. Sentei-me numa caixa e confesso que não foram os pensamentos mais róseos que tomaram conta de mim ao encarar a água agitada. A cada golpe de vara, água limpa saltava para dentro da canoa. Mais de uma vez fomos obrigados a nos puxar com as mãos através do emaranhado de arbustos. A cada avanço escolhia um arbusto no qual me pudesse agarrar numa eventualidade.

Mas o gigante louro, em pé na canoa, imóvel, contou como há pouco tempo remara com toda a família até Porto Feliz, por ocasião do natal. No meio da correnteza a canoa atravessou-se e despejou tudo que continha. Rindo e mostrando os poucos dentes observou que se seguiu uma gritaria assustadora. Agarrou a canoa e segurando a família toda, meio caminhando, meio nadando, dirigiu-se até a margem. Contou os entes queridos. Todos os sete estavam salvos.

Alcançamos sãos e salvos a margem. Pedimos a um brasileiro caçador de onças que mo-

\footnotetext{
22 Escolástico era o nome dado aos estudantes jesuítas, antes de serem ordenados sacerdotes. Na observação, o Pe. Rambo imagina que à margem do Uruguai, em Porto Novo, esses jovens encontrariam o ambiente ideal para estudarem as teses para o exame final, que compreendia toda a Filosofia e Teologia, estudadas durante sete anos. O exame, no jargão jesuíta, era conhecido como "de Universa” (ABR).
} 
rava aí, que nos mostrasse o caminho e 20 minutos mato adentro, topamos com a fonte. De longe percebemos o odor de ovo podre ou, recorrendo a um termo químico, odor de água sulfurosa. A fonte em si resumia-se numa poça pantanosa cheia de água azulada. De todos os lados convergiam a ela trilhas de animais selvagens. Animais e caçadores confirmam que preferem água sulfurosa a qualquer outra.

Dizem que em São Miguel, numa fonte igual a esta - não cheguei a visitá-la - reúnem-se, permanentemente, bandos de periquitos tão numerosos, que basta pegar a espingarda e disparar naquela direção para o pântano se cobrir de verde.

No retorno, o remador embicou a canoa para o meio da correnteza. Disparamos com tamanha velocidade que se tinha a impressão de estarmos imóveis sobre o rio e as margens se deslocarem, céleres, rio acima.

À tarde subi a pé pelo mato até o alto do "Morro da Capela". Neste meio tempo começou uma chuva impertinente, que me frustrou muitas coisas nas duas primeiras semanas. $\mathrm{Na}$ volta ao Schöler esperava-me o sr. Rhode. Na manhã seguinte fora programada a minha visita para as 40 colônias da Linha Itacoruzú ${ }^{23}$.

Acontece que naquele entardecer desceu de novo tanta água do céu que o sr. Rhode, que estava sem correntes $^{24}$, não conseguiu sair da estrada com seu carro de dois lugares, e lhe foi impossível vencer a pequena elevação sobre a qual se encontrava a sua casa.

Senti sincera pena por me ver obrigado a invadir a casa da senhora Rhode, que brilhava, com minhas botas enlameadas. Na frente da

\footnotetext{
${ }^{23}$ Linha Itacuruçu, uma das comunidades do atual município de São João do Oeste, emancipado de Itapiranga em 12-12-1991 (instalado em 01-1-1993) (JNCM).

${ }^{24}$ As correntes aqui referidas faziam parte obrigatória dos acessórios de quem viajava de automóvel ou caminhão cargueiro, nas estradas de terra daquela época. Com as estradas cheias de lama e atoleiros, ajustavam-se as correntes em volta dos pneus para se obter um máximo de aderência, evitando-se, desse modo, ficar atolado ou derrapar para fora da estrada (ABR).
}

cama havia uma pele de coati e pelo espelho da parede encarava-me uma cara que há mais tempo não via navalha. Mas foi uma noite agradável aquela em que conheci, reunida na mesa, a família e todos que faziam parte da vida doméstica do sr. Rhode. Pela primeira vez, me foi dado ver e sentir de perto as alegrias e os planos de um diretor de colônia. Enquanto sentados na sala de estar escutávamos até onze e meia a transmissão da rádio de Buenos Aires ${ }^{25}$ e o sr. Rhode discorria sobre questões relativas à colonização, eu me flagrei sinceramente ignorante, por não entender nada de tudo isto.

Do lado de fora dos tampões ouviu-se a noite toda o crepitar da chuva. E continuou crepitando alegremente ainda na manhã seguinte, quando há muito tempo deveria estar a caminho de Itacuruzú. Pareciam verdadeiras torneiras que despejavam fios de água das nuvens, raras vezes interrompidas por alguns minutos. O tempo bom daquele sábado foi apenas suficiente para conhecer o empreendimento modelo do sr. Rhode.

Apesar de tudo, o sr. Rhode embarcou no seu carro para dar uma chegada em Itapiranga. Acomodei-me numa pesada cadeira de braços marrom, fabricada com madeira nobre por um marceneiro alemão na própria casa e escutei as duas senhoras, o sr. Rhode e a senhora Wirsch ${ }^{26}$

${ }^{25}$ No início da década de 1930 , a posse de um receptor de rádio capaz de receber as ondas curtas da rádio de Buenos Aires no meio da mata virgem do oeste de Santa Catarina, testemunha o espírito daqueles colonizadores. Porto Novo, aliás, foi uma das pioneiras no interior colonial a dispor de central telefônica, que permitia comunicação rápida e eficiente em situações de emergência, como doenças e acidentes (ABR).

${ }^{26}$ Trata-se de Maria Rohde, nascida Wirsch, e de sua mãe, emigradas da Alemanha para os Estados Unidos e que, numa segunda emigração, terminaram na nova fronteira de colonização de Porto Novo. Maria Rohde era cidadã americana e imigrou para o Brasil com o passaporte dos Estados Unidos. Ela se destacou como liderança feminina respeitada na nova colônia. Seu livro, intitulado "Wie eine Frau eine Waldsiedlung wachsen sah - Como uma mulher acompanhou a evolução de um assentamento na mata virgem", oferece informações importantes sobre a colonização de Porto Novo durante as décadas de 1930,1940 e 1950 , com destaque para a participa- 
contar a história de Porto Novo, enquanto se ocupavam com trabalhos manuais.

Começaram com a primeira galinha em Porto Novo. Escondia teimosamente os ovos e numa bela manhã de feriado apresentou um bando de pintinhos. Depois veio a história do primeiro gato de Porto Novo, sentado entre duas galinhas num tronco de árvore no Uruguai, pescando lambaris para ele e elas, apanhando frutinhas que boiavam sobre a água. A história de Leonel Rocha, o comandante de bandos que atravessavam o Uruguai e tiravam dos primeiros povoadores, inclusive do Sr. Rhode, tudo que não levavam no corpo. Uma dúzia de histórias de homens do mato que vinham do lado riograndense, bebiam cachaça sem pagar e atiravam nos outros sem acertar. Duas dúzias de histórias de cavalgadas pelo mato e pela água, num tempo em que Porto Novo não contava nem com médico, nem com parteira. São tantas as histórias que simplesmente enumerá-las já daria um livro, um hino de louvor à vontade de viver e de confiança em Deus dos nossos colonos da mata virgem.

Veio o sábado e a chuva torrencial continuou caindo. À tarde, ao nos arriscarmos para dentro do mato, a água de um riacho insignificante chegou a entrar no cano das botas. Seguiu mais uma enxurrada e, molhados até a alma, fomos enxotados para dentro da casa.

No domingo de manhã o tempo melhorou ao ponto de a família toda poder assistir à missa rezada na "Capela" pelo Pe. Vosskühler. Passei aquele dia em companhia do agrimensor Schickling. Nas três semanas seguintes ele se-

ção da mulher na consolidação da colônia. Maria Rohde teve um papel importante na frustração do confinamento dos colonos alemães natos de Porto Novo, num campo de concentração em Xanxerê. Valeu-se da condição de cidadã americana, abrigando em sua propriedade os deportados a caminho do confinamento, até vir a contraordem das autoridades do Rio de Janeiro e os deportados poderem voltar às suas casas e propriedades. Narra, ainda, as peripécias de colonos brasileiros natos, presos e maltratados durante o período da Campanha de Nacionalização (ABR). ria o meu guia permanente. Na segunda-feira o dia clareou com uma cara sofrível ao ponto de permitir a viagem até Itacuruzú. $\mathrm{O}$ sr. Rhode levou-me rio acima até a desembocadura do riozinho Macuco e a linha do mesmo nome. $\mathrm{Na}$ época não era possível avançar mais. Há pouco o Macuco pregou uma peça sobremodo insolente. Arrancou a pesada ponte dos suportes, derrubou-a dos pilares e levou-a para dentro do Uruguai. Este a carregou inteira pelas corredeiras e curvas, mostrando para quem quisesse ver o conceito que um gigante tem de uma ponte.

Em Itapiranga, uns bons 20 quilômetros rio abaixo, a chegada da ponte foi percebida e, de saída, julgou-se que fosse uma balsa. Dois homens aproximaram-se pelo flanco num barco a motor, fixaram um cabo e tentaram arrastá-la para a margem. Mas o Uruguai não deu moleza. Arrastou consigo a ponte e o barco e, nas proximidades da corredeira do Macaco, para evitar um acidente, forçou os dois homens a cortar o cabo. Somente lá para o sul, em Santo Tomé, na Argentina, o rio jogou as últimas traves da ponte na areia do barranco.

A Linha Macuco se parece com um Bom Princípio em miniatura. Todos aí se chamam Alles, Steffen e Veit e examinando bem a maioria são parentes e cunhados ${ }^{27}$. Nós dois (um alemão há pouco imigrado aproveitou a ocasião para conhecer o mato), apresentamo-nos a Peter Veit, encarregado de mostrar as terras. Colocou o revólver na cintura, passou o facão três vezes no rebolo e mandou que o seguíssemos.

Durante uma hora e meia avançamos terra adentro, seguindo o Macuco. Depois acompanhamos pela direita o arroio Curuzú e, após meia hora, encontramos o mato fechado. A estrada terminou no mato cerrado. $\mathrm{O}$ tronco de uma árvore arrancado por um temporal unia as duas margens. Poucas vezes tive a ocasião para observar um arroio da mata virgem saltar tagare-

\footnotetext{
${ }^{27}$ Como os sobrenomes indicam, a maioria dos pioneiros da Linha Macuco eram oriundos de Bom Princípio, no vale do Caí (ABR).
} 
lando sobre os seixos e camadas de ágata como este Itacuruzú (Cruz de pedra).

Touceiras de taquarinhas tocavam as ondas em ambas as margens e fetos arbustivos margeavam os barrancos. Acima de tudo fechavam-se, em abóbada, os gigantes de um mundo primigênio na quietude abafada da mata virgem.

Aqui ainda não entrara o machado do ladrão de madeira. Tronco ao lado de tronco, entrelaçando as copas, erguem-se os louros, os ce$\operatorname{dros}^{28}$, as cabriúvas, as grapiapunhas ${ }^{29}$ e outras mais. Frente a esta riqueza, os matos das colônias velhas se parecem com vassourais pilha$\operatorname{dos}^{30}$.

Com muita freqüência se faz presente o símbolo dos matos do Uruguai: a canafístula ${ }^{31}$. Pude admirar troncos que, em tamanho e volume de madeira útil, são superados apenas pelos maiores pinheiros. Quando um gigante destes floresce destaca-se nas encostas a horas de distância. Parece-se com a bandeira verde amarela do país, com seus cachos de flores amarelas sobre o fundo verde escuro da folhagem finamente penada de mimosácea ${ }^{32}$.

Efeito bem diferente produz uma outra planta característica do Uruguai, o guaimbé ${ }^{33}$. Ele se agarra de preferência às canafístulas, desce as raízes da grossura de um dedo pelo tronco ou soltas no ar, até o chão, ao mesmo tempo em que desdobra suas enormes folhas recortadas. Âs vezes os pequenos troncos cobertos de cica-

${ }^{28}$ Cedrela fissilis Vell. (Meliaceae), espécie produtora de uma das madeiras mais preciosas da flora brasileira (JNCM).

${ }^{29}$ Apuleia leiocarpa (Vogel) J. F. Macbr. (Fabaceae), árvore produtora de excelente madeira (JNCM).

${ }^{30}$ Descrição perfeita, uma vez que, depois da exploração, a floresta secundária leva muito tempo para readquirir valor madeireiro, no lento processo natural de sucessão (JNCM).

${ }^{31}$ Peltophorum dubium (Spreng.) Taub., Fabaceae.

${ }^{32}$ Descrição exata e com brilho literário, bem ao estilo do notável escritor que foi Balduíno Rambo (JNCM).

${ }^{33}$ Philodendron bipinnatifidum Schott ex Endl., epífita da família Araceae, muito conspícua nas florestas primárias do Alto Uruguai. Em obras mais antigas se encontra o binômio Philodendron selloum K. Koch, atualmente reduzido à sinonímia (JNCM). trizes ficam suspensos nas próprias raízes, se torcem para trás e, amarrando-se umas nas outras, dão a impressão de que todo o conjunto está prestes a cair, à maneira dos anjos rococós nas igrejas. As raízes servem para amarrar balsas e, enquanto verdes, para transmissão telefônica e alta tensão $0^{34}$. O vale do Itacuruzú se parece, em tudo, com milhares de vales em forma de panelão, que emprestam à paisagem do Uruguai a fisionomia típica.

Caminhamos por uma velha trilha de agrimensores subindo a encosta íngreme, por vezes quase a pique. Abaixo de nós enxergava-se o arroio através das copas das árvores. No outro lado estendia-se para longe o chão do vale, plano como uma mesa, delimitado ao longe por outras encostas alcantiladas. Dezenas de fontes jorram das encostas e das fendas e descem até o Itacuruzú. Os lotes coloniais alinham-se em ambas as margens, numeradas alternadamente. Excetuando algumas ladeiras formadas por restos de lajes de basalto, a terra toda pode ser cultivada.

Perto das duas horas alcançamos o planalto na colônia de número 28 , a exatos 400 metros acima do nível do mar (na entrada da picada são 150) e, com ele, as últimas nascentes do Itacuruzú. Não me foi possível observar como de lá para frente as colônias estavam divididas. Não tínhamos levado nada para comer e meu alemão, por princípio, não passava por nenhuma árvore caída no caminho, sem cair por cima dela com seu chapeuzinho verde de caçador, suas calças cáqui, suas magníficas botas e com todo o peso do seu corpo de gigante.

Ao sairmos do mato atacamos em primeiro lugar as melancias, cujo dono regressara a Bom

${ }^{34}$ Esta observação nada tem a ver com um possível uso prático das raízes do guaimbé. Trata-se de um recurso muito usado pelo Pe. Rambo para mexer com a imaginação do leitor (ABR).

${ }^{35}$ Era fato muito comum os pioneiros das frentes de colonização, rapazes e/ou noivos, passarem alguns meses no lote para derrubar o primeiro eito de mato, semear a primeira colheita e construir o primeiro abrigo, para depois voltarem para buscar a noiva, casar e começar a sua história na "colônia nova" (ABR). 
Princípio para buscar a noiva ${ }^{35}$.

Às cinco horas sentamos à mesa. A senhora Veit abriu o forninho (luxo raro naqueles começos) e tirou arroz, feijão, batatas e coxas de galinha, coisa que caía bem depois da inspeção de 40 colônias e para coroar uma marcha de sete horas.

No dia seguinte, Rohde deixou-me na casa paroquial. No caminho encontrei o Pe. Treis que acabara de montar para uma cavalgada até Porto $\mathrm{Feliz}^{36}$.

\section{Incursões no Macaco}

O nome completo do deste afluente do Uruguai é Macaco Branco. Procurei em vão o motivo do nome. Quando no dia 28 de fevereiro me encontrei pela primeira vez com ele, em companhia do sr. Schickling, haviam outros problemas a serem resolvidos. Em condições normais, esse arroio na mata, do tamanho do Cadeia (afluente do Caí, no Rio Grande do Sul), permite tranquiilamente a passagem a cavalo. Acontece que as chuvas da última semana engrossaram em muito o volume da água e o Uruguai, no qual o Macaco desemboca em ângulo reto, represara seu curso inferior.

Havíamos posto a nossa esperança na pequena balsa posta em serviço havia algumas semanas. Como um cachorro desancado, jazia meio submersa na outra margem. Soubemos que naquele dia um morador pretendera atravessar, mas no meio do rio foi colhido pela correnteza e jogado na água com tudo que levava.

Assobiamos para o barqueiro que morava no outro lado, numa pequena choupana. Não demorou e ele aproximou-se, remando numa pequena canoa comprida e estreita. Já à primeira vista ficou claro que se tratava de um alemão nato, porque aqui não se usa chapéu verde e não falava o dialeto francônio. Num segundo momento ficou claro, também, que o homem não nascera na água, pois a frágil embarcação saltitava e dançava com ele sobre a correnteza que

\footnotetext{
${ }^{36}$ Mondai fica a quarenta quilômetros, Uruguai acima (ABR).
}

era um espetáculo.

Tiramos as selas dos cavalos e, quando a canoa finalmente enterrou a ponta no lodo do barranco, tentamos convencer os animais a entrar na água. Mas não foi tão fácil assim. Avançavam até o barranco, baixavam as ventas até a água, sopravam e ficavam imóveis como estátuas. Nem boas palavras, nem gritos, nem empurrões, nem chicotadas os moviam um milímetro do lugar.

Schickling carregou todos os arreios na canoa, acomodou-se na parte de trás, segurou o cavalo pelas rédeas e pediu ao barqueiro que desencostasse. Pretendia certificar-se que o animal o acompanharia. $\mathrm{O}$ barqueiro fez a cara de quem se rende ao destino, passou por cima do monte de arreios, postou-se na parte anterior e começou a remar. Após alguma hesitação o cavalo seguiu de fato o barco e, no final, chegou a nadar na frente da canoa. Desviado pela correnteza perdeu o rumo e foi parar num pequeno arroio secundário, que desembocava ao lado e por fim voltou bobamente até o local onde eu me encontrava. Começou então um teatro que hoje se afigura tanto mais cômico, quanto mais desagradável foi na ocasião. Quando minha mula percebeu que o cavalo de Schickling estava de volta, convenceu-se de vez que o Macaco não era para ela e que, na situação, só a fuga rápida seria a solução. Deu meia volta, deitou as orelhas para trás e teimou em subir o morro. Felizmente o caminho era tão fundo que nos primeiros 20 passos não conseguiu sair. Agarrei a primeira vara que estava à mão, desandei num berreiro assustador e acariciei com pouca delicadeza a cabeça quadrada. A mula voltou assustada e trombou com o cavalo branco. Este escorregou para dentro da água, caiu de barriga no chão, deu meia volta e nadou para a outra margem, onde Schickling o pegou e prendeu.

Depois foi a vez de a mula entrar na água. Em vão fizemos que avançasse para dentro da água além das patas dianteiras. Em vão dissemos aos berros e em voz baixa o que se costuma dizer de bom e de ruim para um orelhudo nestas circunstâncias. Em vão o barqueiro que- 
brou-lhe o remo nas costas. A mula deitou ambas as orelhas para frente, encarou a mancha de espuma que rodopiava na correnteza e permaneceu como que pregada ao chão.

No outro lado, Schickling fumava o segundo charuto. Sugeriu que tentássemos com a mula o que dera certo com o cavalo. Acomodei-me na popa da canoa, segurei o cabresto com o braço estendido para trás e deixei que o barqueiro passasse por mim. Subitamente a mula abandonou toda a resistência como que obedecendo a uma intuição, deslizou para dentro da água e, passando por nós, nadou até a outra margem, onde Schickling e seu cavalo observavam apreensivos.

Respirei fundo e encolhi-me sobre o fundo da canoa que acabara de embicar na correnteza e balançava de forma preocupante. Para mostrar a coragem que se espera de um homem nestas circunstâncias, desviei os olhos da água e olhei para o Schickling, que fumava acocorado. “Cuidado!”, gritou ele para o barqueiro. "A vara é muito pesada!" Este remexia com força na água com o substitutivo do remo quebrado. Em seguida entramos na correnteza. Ela agarrou a canoa, virou-a e a alinhou em direção à corredeira. $\mathrm{O}$ barqueiro procurou escorar a vara no fundo e caiu de comprido sobre a beirada da canoa. Em vez de tentar restabelecer rapidamente o equilíbrio, inclinou-me para o mesmo lado. Em segundos, tudo era água em torno de mim. Quando emergi pude observar o barqueiro agarrado na canoa virada sendo carregado em direção ao Uruguai, enquanto o homem do barranco me alcançava uma vara. Foi a primeira vez na vida que nadei para salvar a vida, vestido de botas, guarda pó e chapéu na cabeça. Ao perceber que tudo iria terminar bem, Schickling rendeu-se ao cômico da situação e riu ao ponto de se ouvir o eco pelo vale do Macaco. Eu da minha parte convenci-me que, a par da formação formal, as sete artes podem ser úteis para um jesuíta.

Evidentemente nem pensar em seguir viagem antes que as roupas estivessem secas. Subimos até a cabana do barqueiro. De início es- tava bem abatido pela desventura por que tinha passado. Sob um telhado de leques de palmeira, aberto para todos os lados, uma panela pendia duma vara apoiada em duas forquilhas e nela fervia o feijão para o almoço. $\mathrm{O}$ barqueiro pegou uma segunda panela, colocou nela três punhados de arroz e acomodou-a junta à panela do feijão. Concordando com a proposta de Schickling, desembolsamos os canivetes e descascamos batatas espalhadas aos montes pela cabana. Enquanto o almoço fervia sobre o fogo, vistoriei os meus instrumentos. Primeiro o binóculo. Tinha engolido água e olhando para dentro por qualquer um dos lados, enxergavase apenas neblina. $\mathrm{O}$ segundo foi o pequeno aparelho fotográfico contendo 30 fotos dos últimos dias. Tudo encharcado, o obturador irremediavelmente emperrado, o filme perdido. Até o relógio tomara água. Somente o altímetro agüentara heroicamente.

O barqueiro levou as três panelas para dentro da cabana e distribuiu os talheres: para ele um prato de alumínio e para mim e o Schickling cada um uma tijela de cerâmica. Na tijela de Schickling estava escrito "revelador" e na minha "fixador". Acontece que todos os alemães imigrados trazem o seu aparelho fotográfico. Ele próprio ficou com a faca, para Schickling entregou o garfo e para mim a colher. Rezou o "Anjo do Senhor" 37 e mandou que nos servíssemos. Em raras ocasiões feijão preto, arroz meio cozido e batata amassada caíram tão bem como naquela tarde, na cabana solitária do barqueiro emigrado da Francônia.

O colono riograndense adota uma atitude de distanciamento dos alemães natos. Será difícil fazer uma avaliação correta do nível de justiça e injustiça neste julgamento. Psicologicamente a coisa é bastante simples. Entre o período da imigração dos nossos antepassados e hoje se interpõem 100 anos da cultura da máquina pe-

\footnotetext{
${ }^{37}$ Nesta singela observação se revela a profunda religiosidade desses pioneiros. Agrimensores, mateiros e caçadores rezavam antes das refeições, nos acampamentos. O que não esperar do povo no seu quotidiano! (ABR).
} 
sada, 100 anos prenhes de terremotos políticos e mudanças bruscas na história da Europa. Enquanto estes fatos mal tocaram o nosso colono, a alma européia sofreu profundas revoluções. O colono percebe logo a maneira de ser bem diferente do imigrante. Isto o torna desconfiado. De outra parte, o estrangeiro leva desvantagem em questões práticas, o que resulta em caçoadas e menosprezo. Se o estrangeiro se apresenta de nariz empinado e não aceita lições, a paciência acaba de vez. Mas quando demonstra vontade honesta de trabalhar e permite que o ensine, o que, graças a Deus, é o caso da maioria de Porto Novo, o alemão nato se dá bem. Teríamos uma dúzia de exemplos para comprová-lo. Toda esta situação é superada com o bom senso e a caridade cristã.

Na mesma tarde cavalgamos até a Linha Presidente Becker ${ }^{38}$, que encosta no Peperi. Visitamos os alemães natos e pernoitamos na cabana de um grupo de construtores de estrada. Não foi brincadeira. Os torturadores da mata virgem, os mosquitos, penetravam aos enxames, apesar do fogo e dos mantos que cobriam até as orelhas. Uma ardência que não deixa dormir toma conta do rosto, pescoço e mãos, até que o frescor da madrugada faz com que os sugadores de sangue se recolham aos seus esconderijos.

A manhã do dia primeiro de março começou bem variada. Primeiro fomos a cavalo até o final da construção da nova estrada e tentamos avançar por uma outra trilha. Ao chegarmos a um pequeno arroio, convencemo-nos que era preciso apear. Schickling avançou na frente com

\footnotetext{
${ }^{38}$ A Linha Presidente Becker recebeu esse nome em homenagem a Jacob Becker, irmão de Dom João Becker, arcebispo de Porto Alegre. Durante muitos anos, Jacob Becker foi presidente da Sociedade União Popular, a colonizadora de Porto Novo. Em sua grande maioria, os moradores da Linha Becker eram alemães natos, emigrados por causa do nazismo. Tratava-se de pessoas de formação apurada, alguns, inclusive, com curso superior, caso do Sr. Lenz, que era advogado. Paradoxalmente, durante a Campanha de Nacionalização eles estiveram a ponto de ser confinados num campo de concentração em Xanxerê, sob a acusação de nazistas (ABR).
}

o facão na mão. Atravessamos o arroio e nos afastamos dele, subindo uma encosta íngreme. A certa altura, onde à esquerda não havia nada além de uma rocha coberta de taquarinha, três metros acima da água, o cavalo de Schickling ficou preso com a pata traseira esquerda, numa vara inclinada. Em vez de puxar com vagar, o tolo do animal começou a pular e não parou até que se precipitou por cima da taquarinha e da rocha para dentro do arroio. Ficou deitado por alguns segundos, pôs-se novamente em pé e, pulando loucamente, procurou livrar-se. Neste meio tempo o alforje caiu da sela, enrolou-se nas pernas traseiras e, por várias vezes, batido sobre as pedras. Quando Schickling alcançou-me o saco imaginei que todos os meus pertences estivessem definitivamente reduzidos a cacos. Desta vez, entretanto, não tinham sofrido dano.

Quando ao final de duas horas encontramos a trilha, decidimos cavalgar diretamente até o Macaco superior, onde trabalhava a equipe de Schickling. Primeiro avançamos a pé, porque a vegetação que cobria a trilha não permitia a passagem a cavalo.

De saída passamos pela propriedade de um alemão nato. Passando pelo dorso de um morro descemos a encosta íngreme. No fundo rugia a água de um rio e, de vez em quando, o espelho da água brilhava por entre os feixes de raízes de guaimbé. Alcançamos o barranco e fiquei admirado que naquela altura do seu curso o Macaco parecia ser mais volumoso do que na desembocadura. Mas Schickling ficou ainda mais admirado porque não encontrou o caminho esperado e números de lotes desconhecidos. Ao que tudo indica, observou ele pensativo, estamos no Macaco muito acima do que pretendíamos. Pediu que eu esperasse até que ele se localizasse. Voltou, sem demora, com a notícia que nós nos tínhamos perdido em algum lugar e não havia outra saída senão voltar a subir o morro.

Foi uma empreitada ingrata ao sol do meio dia e com o estômago vazio. Além disto, a minha montaria apressada pisava-me infalivelmente nos calcanhares quando eu diminuía a marcha. Chegados ao alto, desencilhamos os ani- 
mais, deitamo-nos ao lado da cabana do alemão e almoçamos algumas espigas de milho meio maduras.

Schickling procurou em vão o caminho. Só quando o morador voltou para casa ao meio dia, ficou claro que não estivemos no alto Macaco, mas no Peperi. Neste ponto os dois rios aproximam-se ao ponto que apenas uma pequena elevação os separa, confundindo o maior vaqueano. Depois do almoço descemos até o verdadeiro Macaco em companhia do morador solitário do mato. Mas o atraso foi tamanho (mais dois cavaleiros se associaram a nós) que chegamos à saída do mato ao anoitecer e faltavam ainda cinco quilômetros até o acampamento dos agrimensores. Foi a marcha mais cansativa de toda a viagem. Com o facão numa mão e o cabresto na outra, avançamos em marcha de ganso, ora por declives de pedra, ora por leitos pantanosos, ora perdidos no emaranhado desalentador da taquarinha. Há muito tempo Schickling queimara todos os fósforos e a lua ainda não tinha nascido e não se vislumbrava o fim. Sacou o revólver e fez um disparo. De muito longe, quase inaudível, veio a resposta. Um segundo disparo e a resposta e continuamos tropeçando pelo pântano e a taquarinha que estalava.

Depois de duas horas o brilho pálido da lua começou a mostrar-se por entre os troncos das árvores. As vozes dos agrimensores podiam ser ouvidas vindas do outro lado. Da outra margem! Foi exatamente este o lado mais louco da questão. Às nove horas da noite fomos obrigados a atravessar o impetuoso Macaco para chegar até o acampamento.

Conduzi a minha montaria até o local onde os homens afirmavam achar-se a passagem, embora não identificasse nada além de um tronco de árvore à esquerda, à direita moitas retorcidas e no meio, três metros abaixo, água refletindo a luz da lua. É claro que a mula se recusasse a descer. Os homens colocaram-se atrás dela e, vupt, afundou no Macaco até as orelhas e à altura dos canos das botas. Uma vez dentro, rumou valentemente em direção à tocha do outro lado. De vez em quando a correnteza passava por cima do pescoço, desviando-a um pouco rio a baixo, até um leito de pedras irregulares. Felizmente alcançamos ambos a outra margem. Em menos de meia hora aconteceu o mesmo com os outros acompanhantes. Schickling permanecia na outra margem. Nenhum poder do mundo foi capaz de convencer o tordilho a deslizar para o fundo que marulhava. Schickling já decidira passar a noite no outro lado quando um dos homens foi socorrê-lo, atravessando o rio com auxílio de uma vara.

$\mathrm{O}$ acampamento dos agrimensores (quatro homens e um rapaz) se encontrava 100 metros adiante, na margem de um arroio. Duas cabanas, uma aberta para todos os lados e a outra com telhado, aberta em ambos os lados apoiada no chão, formavam o conjunto. Uma enorme panela de feijão fumegava suspensa numa vara. Acomodamo-nos em sua volta, enrolados em nossos ponchos e nos deliciamos com o perfume que escapava por debaixo da tampa que saltitava. E, eu aposto que, se pai Homero tivesse sido agrimensor na mata virgem de Porto Novo, não teria chamado o "fraco trigo", mas o feijão, de "cerne do homem".

Ninguém tem o direito de exigir de mim para contar todas as histórias verossímeis e inverossímeis com que um dos agrimensores nos brindou naquela noite e nas outras que se seguiram, junto ao fogo do acampamento. Apenas uma outra como amostra! Sua "beleza", uma cachorra de indescritível magreza, que corria atrás de todo e qualquer toco de cigarro suspeitando que fosse comestível, certa feita surrupiou da vizinha uma forma cheia de massa de pão diante do forno e, sem a virar, carregou-a 200 metros para dentro do mato. Passando casualmente pelo local, encontrou-a deitada de barriga diante da massa, deleitando-se passava a língua por cima, abanava o rabo, cônscia da sua culpa, quando ela a repreendeu. "Beleza, onde o afanaste?"

Para o dia seguinte tínhamos planejado ir a pé até o rio Peperi, a fim de vistoriar uma fonte sulfurosa aí existente. Mas, por conta da instabilidade do tempo, optou-se por uma caçada de 
veado. A cachorrada latiu a manhã inteira pelo mato sem levar animal algum ao alcance do tiro. Três pacas surpresas jogaram-se diante dos nossos olhos no Macaco.

Passado o meio dia pusemo-nos a caminho de casa. Perdemos irremediavelmente a trilha. Sabíamos apenas que nos encontrávamos nas nascentes do arroio, nas margens do qual estava o acampamento. Concluímos que seria fácil, bastando seguir o arroio. A coisa correu bastante bem na primeira e também na segunda hora. De lá para frente, a água subia acima dos pés e nos sentíamos felizes por calçar botas à prova de água. Um pouco mais tarde as primeiras lambidas de água saltaram para dentro da bota e, no final, nada mais importava. Cada vez que Schickling erguia o pé de dentro da água e o descansava sobre uma pedra, a água esguichava de todos os furos como se fosse um chafariz. O resultado foi que, durante quatro horas, acompanhamos todas as voltas do arroio, descemos todas as cascatas e cambaleamos através de todos os poços, até que, ao anoitecer, chegamos ao acampamento e nos resignamos a passar mais uma noite nele.

$\mathrm{O}$ que se conversou naquela noite não foi nem muito interessante nem muito inusitado, mas magistral. Lembro-me de modo especial do homem que ouviu o seu cusco latindo no mato, tirou a espingarda do prego e foi conferir. Enquanto afastava a taquarinha que envolvia as raízes em forma de tábua de uma figueira, saltou na sua frente um tigre em corpo e alma. De puro susto nosso homem puxou os dois gatilhos e descarregou os dois cartuchos de chumbo entre as orelhas do monstro e, urrando de susto, pôs-se a correr. Perdeu os tamancos, o chapéu e a arma pelo mato, ao mesmo tempo em que rompia cipós da grossura de um braço. Na volta todos o consideraram maluco, mas quando foram verificar, encontraram o rei da mata virgem morto, deitado sobre a taquarinha, com os dois olhos vazados pelo tiro. Desde então o homem goza da fama de maior caçador de Porto Novo. Quando o contador de histórias percebeu o quanto o "estudante" apreciava as suas "mentiras", a chama do seu entusiasmo transformou-se em fornalha. Falou do puma que durante a noite se esgueira pelo acampamento, ora miando como um gato, ora chamando como um macuco, ora gritando como uma coruja, mas de resto não passa de um trapalhão inofensivo. Descreveu como os porcos do mato, de focinho baixo, perseguem os cachorros, mastigando espuma, batendo os dentes, e os reduzem a frangalhos quando os alcançam. Falou dos muitos animais e seus hábitos, num tom pelo qual se percebia o quanto conhecia e amava o mato e tudo quanto nele vive.

Não poucas vezes pareceu-me que me encontrava, não no Macaco que lá em baixo cava buracos nas rochas, mas na fonte eterna da poesia épica, não no Macaco, mas em frente às muralhas de Tróia, não sob os gigantes da floresta subtropical, mas nos bosques de carvalhos de Ítaca, onde Eumaios, o pastor de porcos, levava seus rebanhos até a fonte negra e que o nome deste homem magro com o bigode ralo, o alforje sempre em volta do pescoço, não era Hermann Sehn, mas o "pai Homero", pois a alma artística inofensiva e inconsciente do homem homérico não envelheceu no decurso dos milênios e, para que os desocupados do século vinte percebam um sopro sequer dela, é preciso ir até o fogo do acampamento dos agrimensores e dos caçadores de porcos selvagens.

Desta vez, nada feito com o descanso durante a noite. As montarias andavam soltas e principalmente o tordilho trotava sem parar em volta da cabana, farejavam na cobertura de folhas de palmeira e sopravam de leve como se tivessem percebido algo estranho. No meio da noite, o berro de um dos agrimensores acusou que alguma coisa o mordia nos dedos do pé. $\mathrm{O}$ criminoso foi de novo o tordilho que, aliás, se sobressaía por seu caráter impressionável.

Quando uma mutuca o picava atrás da orelha, vinha correndo e, na falta de um tronco de árvore, esfregava-se com tamanho ímpeto no ombro do primeiro homem que encontrava que o fazia cambalear para o lado.

O dia três de março amanheceu com cerração úmida. Entre os agrimensores serve-se, en- 
tra dia, sai dia, a mesma refeição, ou arroz com feijão ou feijão com arroz! Ao clarear do dia saem de dentro das folhas de palmeira, ativam o fogo, requentam o feijão que ficou a noite toda pendurado sobre o fogo, enchem três ou quatro pratos de folha, servem um mate antes, durante e depois da refeição, empunham a foice de roçar, afivelam o facão na cinta, carregam o teodolito no ombro e partem para o mato. Nós montamos e partimos para Itapiranga.

\section{A grande cavalgada}

A esta cavalgada precede uma pequena história. Quando o Rohde me levou a primeira vez para a parte superior da colônia, mencionou de passagem que no decorrer dos próximos dias viajaria até Chapecó para algumas tratativas com o prefeito e perguntou-me se estava disposto a acompanhá-lo.

É óbvio que eu estava disposto, pois a excursão não poderia durar mais do que uma semana. Quando retornei à casa paroquial e me ocupava em acondicionar as minhas plantas para o "forno" (forno de tabaco de um colono), aproximou-se Schickling com a seguinte notícia: Rohde recebera um telegrama de Passo Fundo com o pedido que, em função de negócios, se dirigisse imediatamente para lá. Viajara na manhã do dia anterior. Era seu desejo insistente empreender, apesar de tudo, a viagem até Chapecó. Schickling, Haubert e o escrivão iriam de qualquer maneira e, se quisesse, poderia associar-me a eles. Colocava à disposição o seu cavalo e arreios e não haveria despesas na viagem.

Lembrei-me que o Pe. Provincial recomendara ao Rohde que me fizesse circular um pouco por aí. Fiz rapidamente a conta do tempo de que ainda dispunha e dirigi um olhar de interrogação ao Pe. Vosskühler. Este se limitou a dizer: "Sim, acompanhe-os".

Parti com eles, isto é, primeiramente acompanhei Schickling até o prédio da administração, perto do Uruguai. Haubert nos esperava de lenço no pescoço, colete, botas e esporas, o trabuco na cintura. Corria do escritório para dentro da casa, da casa para o pátio e de novo para dentro da casa. Empacotava papéis, pensativo passava a mão no queixo barbeado, chamando ao mesmo tempo o peão. Neste meio tempo o filho menor uivava agarrado no avental da mãe, porque o pai se ausentaria por mais de três semanas, E, quando finalmente trotamos para a estrada principal, quatro meninas de cabelos encaracolados gritavam a plenos pulmões, debaixo das laranjeiras históricas ${ }^{39}$ de Porto Novo: "Adeus, papai!"

Escurecia naquele sábado de tarde quando alcançamos o arroio Dourado. Eram oito horas e noite fechada quando chegamos à casa dos Rohde. Naquela noite a palavra foi minha, pois vivenciara uma parcela da história dos começos de Porto Novo. E posso garantir. As duas mulheres, a cozinheira da região de Salzburgo, o carpinteiro da Westfália e o peão do Rio Grande do Sul escutaram a história do meu mergulho no Macaco, com reconhecida gratidão. E foi uma sensação de rei poder deitar-me para dormir no quarto comprido, com a colcha trabalhada e a pele de coati, depois de uma noite minada de mosquitos no acampamento dos construtores de estrada e duas outras com os cavalos farejando em volta da cabana de leques de palmeira dos agrimensores.

Tínhamos combinado no dia anterior seguir caminho o mais cedo possível. Acontece que o homem que sempre esquece o relógio sobre a mesa de trabalho ou aquele que o usa como ornamento no bolso do colete entende o conceito "cedo" de maneira diferente. Com isto dispus tranqüilamente de tempo para ocupar-me na frente da casa com a minha meditação da manhã, enquanto a senhora Rohde, lá dentro, cantava e rezava o terço com as crianças. À tarde sobrou ainda tempo para conversar com um alemão, que reclamava para si a honra de ser o pri-

\footnotetext{
${ }^{39}$ Referência ao primeiro pomar de laranjeiras plantado em Porto Novo, em cuja sombra o Pe. Max von Lassberg rezou a primeira missa na colônia de Porto Novo, em 31 de julho de 1925, assistida pelos primeiros colonizadores (ABR).
} 
meiro morador de Porto Novo. Muito antes que a Sociedade União Popular pensasse em fixarse aqui, este homem, se não me engano procedente da Baviera do Norte, estabeleceu-se com seus filhos no meio do mato, no médio Macuco. Ouvira falar de algum lugar em que as terras em volta já tinham sido vendidas e o progresso estava à porta.

É fácil imaginar o que significou para um alemão o isolamento por anos naqueles ermos. A fronte maltratada pelo tempo e as duas crianças que faleceram o comprovam. Mas a magnífica propriedade no Macuco e a inquebrantável vontade de viver deste homem provam, também, que o alemão diretamente imigrado também se presta para colonizar. Pode acontecer que no começo semeia o milho, ou se decepciona com $\mathrm{o}$ amendoim que floresceu bem mas não carregou vagens, que deixa um brasileiro lhe extrair os bichos-de-pé e, para cada um, paga um mil réis, ou se dá mal e procura outro lugar. Não é a regra, é a exceção. Trata-se de devolver uma casa e uma querência nova ao órfão da sorte, muitas vezes crescido na miséria e, não raro, espiritualmente desenraizado. Desta forma renascem primeiro como homens e, depois, voltam ao cristianismo que fora soterrado. Sendo assim, a Sociedade União Popular não cuida apenas do socorro das próprias necessidades, quando assenta alemães nas colônias que os colonos riograndenses refugam por causa dos mexericos sem sentido ${ }^{40}$. Pratica, também, uma obra de caridade cristã quando ajuda os imigrantes a construir uma nova querência.

Aproximava-se das 10 horas quando Schickling e Haubert finalmente apareceram. Schickling estava todo invocado com a mula que tinha trazido para mim desde o Schöler. Por duas vezes o espertalhão marrom negro, suspeitando porque fora tirado solenemente da estrebaria, se livrou do cabresto e simplesmente fugira.

\footnotetext{
${ }^{40}$ Referência às críticas de pessoas que desaconselhavam a compra de terras em Porto Novo, inventando problemas ou exagerando as dificuldades encontradas pelos colonizadores (ABR).
}

Ainda a esta altura manifestava prazer em escoicear ao ser encilhado, enquanto guinchava perigosamente.

No momento em que me punha a subir na montanha de pelegos argentinos, vermelho-marrom de Rohde, vi que o meu guarda-pó (isto é, pertencia propriamente ao irmão Rabuske) se encontrava em estado deplorável. A senhora Rohde buscou um dos seus. Mal alcançava os joelhos e descia um pouco abaixo dos cotovelos. Eu me parecia com o padre quando ensina a doutrina cristã no domingo de tarde. Mas serviu e ninguém teve a idéia de me dar um novo com um corte mais adequado.

Trotamos Uruguai acima. Na Linha Chapéu, o povo acabava de sair da missa dominical. Schickling tinha de cuidar de um negócio e ficou um pouco para trás enquanto eu e Haubert atravessamos o Macuco. Haubert lembrou-se que carregava uma garrafa com um conteúdo reanimador. Mas quando se pôs a abrir, a rolha escorregou para dentro. Quando Schickling nos alcançou e não achando rolha sobressalente em seu alforje, Haubert viu-se obrigado a abrir mais de uma dúzia de espigas de milho semimaduras, até encontrar um sabugo com a consistência suficiente. Depois de montarmos de novo, cantou um hino de louvor aos pastéis de carne que a mulher lhe empacotara e que almoçaríamos em seguida. Não suspeitava que fim desastroso teriam.

No arroio Catres termina Porto Novo, abruptamente. A bem conservada estrada do Uruguai avança até a água. No outro lado, porém, começa um caminho difícil, pântano no começo, depois "franceses" ${ }^{41}$ e nada mais que "franceses". Fecham por cima da cabeça e, à direita e à esquerda, passam por cima do pescoço do animal e jogam as sementes aladas no rosto da gente, ao ponto do cavalgar se assemelhar mais a um nadar.

\footnotetext{
41 "Franceses" era o nome dado a um arbusto que chega a dois ou mais metros de altura, de flores amarelas e que prefere terrenos recém desmatados (ABR).
} 
Aqui percebi pela primeira vez, com clare$\mathrm{za}$, o ilhamento dos assentamentos no Uruguai. A estrada comum de acesso, que vem de Santa Bárbara até Palmeira das Missões, se bifurca em dois braços atrás de Fortaleza. O esquerdo desce para Porto Novo. O direito bifurca-se novamente em Barril ${ }^{42}$, direcionando-se o ramal esquerdo para Porto Feliz e o direito segue para Mel, Passarinhos, Palmitos e São Carlos. Essas colônias gozam de uma precária comunicação entre si, ao ponto de cada uma se parecer mais como um prolongamento do Rio Grande do Sul.

No alto, depois do arroio Catres, começa o território de Porto Feliz, reconhecível pelo fato de os "franceses" terem sido roçados. Não demorou para encontrarmos o primeiro morador e com ele fizemos meio dia. Também ele é um dos primeiros que vieram do Rio Grande do Sul para estes ermos.

Das muitas histórias contadas durante o chimarrão, escolho uma, acontecida em Porto Novo, por ser muito ilustrativa do caráter de nossos colonos. O sapateiro Kunz, um teutoromeno, aprontara um par de tamancos para o velho comerciante Weiss. Como o sapateiro Kunz gostava de pregar uma boa peça, omitiu os pregos de maneira que na primeira caminhada o velho Weiss perdeu a madeira e o couro. $\mathrm{O}$ velho Weiss pegou uma folha de papel, mandou escrever à máquina uma frase em português, colou o maior número de selos, foi ter com os amigos e pediu que assinassem. Um intermediário levou o escrito até o sapateiro, explicou que se tratava de um requerimento para corrigir algumas aberrações na colônia. Cheio de satisfação, o sapateiro rabiscou seu nome. Duas horas mais tarde apresentou-se o velho Weiss, seguido por uma delegação e traduziu para o alemão o documento: "Pede-se que em Florianópolis se tenha a bondade de mandar dois policiais para libertar Itapiranga do sapateiro descuidado, que

${ }^{42}$ Primeiro nome de Frederico Westphalen. O nome veio do fato de que na beira da estrada que passava pelo local havia uma fonte que era recolhida num barril, para as pessoas e animais que passavam matar a sede (ABR). nem sequer um par de tamancos é capaz de confeccionar". No momento em que o colono é chamado a subscrever um papelucho qualquer, mesmo que signifique uma condenação à morte, ele se sente honrado. E não pouca estupidez de tamanho maior nas colônias tem a sua origem nesta fraqueza do homem simples.

As redondezas do arroio da Taipa forma uma das paisagens mais grandiosas de todo o médio Uruguai. Em parte nenhuma o formato de panelão fica tão evidente como aqui. Não demora e percebe-se a diferença fundamental entre Porto Novo e Porto Feliz. Enquanto lá, a cada meia dúzia de quilômetros parte uma estrada do Uruguai e leva ao "hinterland" afastado e povoado, aqui uma estreita faixa cultivada costuma acompanhar a estrada principal.

Ao por do sol entramos em Porto Feliz. O povoado encontra-se numa localização em relação ao rio como Itapiranga, só um pouco mais alto, avança mais terra adentro e conta com mais habitantes e mais casas de alvenaria. Parece que aqui o povoamento se encontra num compasso muito mais lento do que em Porto Novo, principalmente desde que a comunicação com Porto Novo não passa mais por Porto Feliz.

Foi um caro custo até nos pormos em movimento na segunda-feira de manhã. Haubert tinha negócios a resolver junto ao escrivão e Schickling, que há doze anos sobe e desce o Uruguai, visitou os conhecidos.

Depois de trotarmos por uma hora alcançamos antes do meio dia o rio das Antas, limite entre Porto Feliz e as terras de Culmey ${ }^{43}$. Encontramos um rapaz e uma moça que haviam pernoitado na mesma estalagem que nós. Per-

${ }^{43}$ Karl Culmey, engenheiro agrônomo. Embora protestante, foi o braço direito do Pe. Max von Lassberg na colonização de Cerro Largo e Santo Cristo, bem como de San Alberto, na província de Missiones (Argentina). Depois disso, empreendeu colonizações no Alto Uruguai. Morreu afogado no rio Uruguai. Sua filha Tutz acompanhou-o nessa empreitada como secretária e deixou suas experiências publicadas num livro com o título "Die Tochter des Pioniers - A Filha do pioneiro" (ABR). 
tenciam ao assentamento teuto-russo de Iracema e de casa se assinavam Zimmer. Admirei o seu alemão impecável que combinava pouco com os traços eslavos do rosto, mas de acordo com o tom melancólico próximo ao fatalismo com que falavam da Rússia. Depois de fugir com dificuldade e sofrimento do inferno do Volga, foram retidos por muito tempo em Moscou e alguns aleatoriamente autorizados a emigrar e outros mandados de volta. Da família Zimmer, a mãe e os filhos ganharam liberdade e o pai foi obrigado a retornar. Morreu de fome! concluiu o jovem e olhou para a mão ensangüentada e a calça em frangalhos dos joelhos para baixo. Pouco antes sua montaria tropeçara e o jogara no arame farpado.

Passado o rio das Antas recomeçou a contar. Ao que tudo indica, Culmey entrou numa fria com a colonização teuto-russa. Providos excessivamente pelo governo alemão, os imigrantes comportaram-se à maneira bolchevista no acampamento do arroio Iracema e mais tarde no próprio acampamento. Trocavam roupas e equipamentos por cachaça, promoviam algazarras, brigavam e demoliram a escola.

Não ficou bem claro como é que se deram os fatos. O certo é que Culmey despachou uma parte dos imigrantes para o Uruguai. Encomendou para esta finalidade uma embarcação chamada na região de "Pirágua" (em Porto Novo escutei, também, o nome "Pira de Água"), um tipo de barco da melhor madeira, vendido no fim da viagem junto com a carga. O construtor, preocupado em poupar, fez o barco muito pequeno. Culmey ameaçou-o com tudo de ruim na hipótese de se perder uma única das 500 pessoas. Terminada a viagem mandou dizer que não somente não perdera um único passageiro, como chegara às praias uruguaias com dois cidadãos do mundo a mais.

Neste meio tempo nos aproximamos do assentamento. Um homem com rosto anguloso, tipicamente eslavo, o boné ensebado sobre o crânio redondo e a espingarda de caça com a boca apontando para o chão, atravessada sobre a sela, por debaixo da perna esquerda. Em Ira- cema ainda se podem ver as pequenas cabanas incrivelmente precárias, nas quais moravam no início os imigrantes. Ao lado predominam bonitas casinhas de madeira com cinamomos na frente. Na varanda de uma destas cabanas de troncos de árvore, tabuinhas, varas e barro, uma mulher lidava com as panelas. Sob o chapéu de palha aparecia o rosto enrugado como uma velha escultura de madeira. Era a senhora Zimmer, cujo marido morreu de fome no Volga e cujos filhos tinham conquistado aqui uma nova querência. Mesmo que tivéssemos que comer batata doce crua, ainda era preferível do que estar na Rússia, disse-me a moça no caminho. Na média são protestantes. Pelo meio dia entramos em Iracema. Ao lado da escola, até há pouco muito maltratada por beberrões, funciona uma cooperativa de compra e venda, ao molde daquelas que se tornam cada vez mais freqüentes no Uruguai.

Schickling e eu nos dirigimos diretamente para a estrebaria, enquanto Haubert desencilhava o cavalo na frente da casa. Apareceu depois o administrador do negócio, um teutorusso com boné na cabeça. Com sua vozinha fina perguntou se aqueles dois senhores lá em baixo eram fiscais. Tranqüilizado quanto a isto, abriu e permitiu que entrássemos. Por 300 réis serviu um copo de cerveja com cachaça aos homens, com a observação que doses menores não faziam parte dos hábitos locais.

Acomodamos-nos no avarandado para o almoço. Dois alemães, um renano e um silesiano, tomaram lugar conosco. Depois de falar sobre isto e aquilo, o renano perguntou se no Brasil havia também jesuítas. Sim, várias centenas e também eu era um. O homem arregalou os olhos e contou que fora doméstico dos jesuítas na Índia. Nomeou de fato alguns nomes. O outro se chamava Ablass, vestia uma calça caqui e uma blusa marrom. Elogiou o padre vigário de São Carlos como sendo um senhor bastante educado.

Neste meio tempo, enquanto nos demorávamos aí e esperávamos pela tarde mais amena, aproximou-se um caçador. Acompanhava-o um 
rapaz com uma fisionomia estranhamente abobada e um cachorro que, de tanta sarna, quase perdera todo o pelo sobre as costelas e de uma magreza que dava pena. Neste momento Haubert foi acometido de uma inspiração repentina. Foi até os arreios, abriu o alforje, tirou um embrulho de jornais e tirou os famosos pastéis de carne da mulher, objeto de referências elogiosas nos últimos dias. De longe foi possível deduzir do seu rosto que os pastéis não cheiravam mal, mas desprendiam, isto sim, um odorzinho. De coração pesado jogou-os para os cachorros. $\mathrm{O}$ cusco engoliu-os com tanta voracidade que dava vontade de chorar.

Desde o começo Haubert vinha fazendo referências nada elogiosas ao costão depois do arroio São Domingos, que deveríamos cruzar ainda naquele fim de tarde. A trilha que leva até o pequeno rio que marulha com força, na borda íngreme de um típico panelão, resultado do desmoronamento, achava-se a tal ponto oculto que qualquer estranho passaria sem percebê-lo. Todos esses arroios marulham sobre as rochas com sua água maravilhosamente límpida, ladeados em grandes extensões por arbustos "quebra-foice", cobertos de flores vermelhas ${ }^{44}$. A travessia não se dá sem riscos. A qualquer momento o animal está sujeito a pisar num buraco e quebrar os ossos.

Desta vez foi tudo bem. Havia vinte minutos que descíamos ao longo do arroio para então começar a subir, quando Haubert se lembrou que tinha deixado o casaco no outro lado do arroio São Domingos. Foi até lá a pé e voltou tarde, ofegante e com as roupas molhadas.

Aqui em São Domingos tive pela primeira vez a compreensão do que é uma paisagem de mata virgem. Sobe-se em zigue-zague por 170 metros a encosta quase à pique e coberta de mato. A 400 metros encontramos um dorso plano como uma mesa, de cerca de 200 passos.

${ }^{44}$ Calliandra tweediei Benth. (Fabaceae), arbusto também chamado de topete-de-cardeal (JNCM).
Depois descemos uma encosta da mesma altura e igualmente íngreme, em cujo sopé passa um arroio impetuoso.

Com inúmeras variações, este esquema predomina do Peperi ao Chapecó. Compõe a paisagem uma poderosa cadeia formada por morros da mesma altura (entre 350 a 400 metros), cobertos de mato, separados por vales em forma de panela, nos quais os cursos de água tocam ora numa ora na outra encosta íngreme.

Pernoitamos em Palmitos, localizada 10 quilômetros para o interior, uma povoação asseada e inteiramente protestante. No dia seis de março, terça-feira, conseguimos finalmente montar cedo, porque neste dia, embora me parecesse improvável, tínhamos a intenção de chegar até o Passo dos Índios.

De todos os caminhos as crianças das escolas vinham ao nosso encontro, saudavam, viravam-se e ficavam nos olhando.

Pela primeira e última vez encontrei nesta abençoada terra um recurso que não custa nada e poupa muito trabalho ao viajante. Em todos os caminhos haviam placas orientadoras! Em não poucas estradas brilhavam as mais belas ágatas e ametistas. Uma dezena de vezes saltase da sela para escolher as mais bonitas. No seguinte corte de estrada são ainda mais vistosas. Jogam-se fora as primeiras e procuram-se outras. No fim a gente carrega por aí as mais bonitas até que furam o bolso. Então também estas voam para o mato.

Uma estrada sofrível vai de Palmitos a São Carlos. Ambas as localidades pertencem ao território de Culmey. $\mathrm{O}$ aspecto é o mesmo de Porto Feliz. Em ambos os lados uma faixa de terra cultivada, mas quase sem uma penetração maior para os fundos. Antes de descer para Barra Funda abre-se uma das mais belas vistas que me foi dado gozar em toda a viagem. Para além do vale em forma de panelão estendem-se, à esquerda, as terras de São Carlos e Chapecó. Em frente, à direita, brilha a lâmina prateada do Uruguai. Lá longe os dorsos dos morros elevamse gradativamente, tornam-se planos e transfor- 
mam-se num planalto. Esta é a "Serra", a tonalidade escura vem das florestas de pinheiros ${ }^{45}$.

São Carlos, inteiramente católica, encontrase na porção anterior da enorme depressão pela qual passa à direita o Uruguai e à frente o Chapecó. Não estou em condições de mostrar até que ponto o assentamento se distingue dos outros. Dá a impressão de um progresso extraordinário. Como em Porto Novo, a igreja é de madeira. A construção da casa paroquial, ao lado, estava na altura das janelas.

Sem nos demorarmos seguimos em direção a Chapecó. O italiano Vittorio levou-nos com sua balsa até o outro lado do rio, que deve ter a largura do Caí em Pareci, no Rio Grande do Sul.

Mais uma vez, e pela última, desenha-se o caráter da paisagem. Olhando do meio do rio em direção à cabeceira, alonga-se um amplo vale em forma de panelão, no qual brotam as maiores fontes sulfurosas de todo o Uruguai. Olhando para o Uruguai em direção oposta, um paredão íngreme de perto de 300 metros fecha o vale. Este corta a passagem do Chapecó para a direita, imediatamente antes da sua embocadura.

$\mathrm{Na}$ hospedaria de Ohland soltamos os animais e encomendamos um almoço e, sem perda de tempo, nos dirigimos até "Águas do Chapecó." Atravessando um potreiro coberto de arbustos, descendo por uma trilha escorregadia chegamos a uma sanga. Aqui, bem ao lado do Chapecó e quase ao nível do seu espelho, borbulham as misteriosas fontes que um dia serão conhecidas mundialmente. Emergem aos borbotões da lama negra, escorrem por sobre a rocha, reúnem-se na sanga e perdem-se no Chapecó.

Duas delas foram captadas em poços feitos com cano. De um azul profundo, a água sobe pelos troncos de árvores ocas, fumega levemente na superfície e num jato da grossura de um braço, cai num recipiente de madeira, sem fazer barulho, como se contivesse sabão.

\footnotetext{
${ }^{45} \mathrm{O}$ pinheiral, ou floresta com araucárias, na obra de Rambo, muitas vezes é referido como "Mata Preta" (JNCM).
}

Afirmam que as fontes avançam rio adentro, um fato que pode ser observado em vários pontos no Uruguai, no rio do Mel e, provavelmente, também no Peperi. Aliás, as imediações do rio Chapecó oferecem todas as características clássicas de um terreno propício para fontes sulfurosas. Proliferam aí as "Águas" quentes e frias, "Aguinhas" e "Barreiros". Muitos colonos possuem um ou dois no seu lote.

$\mathrm{E}$, ao mergulhar a mão nesta água morna, macia como veludo, entra-se em contato com as derradeiras pulsações daquele acontecer gigantesco que, pelo final do Triássico, cobria o sul do Brasil com basalto e meláfiro e preparou as bases da sua agricultura.

Mas para a pessoa que aprecia água fresca e não sofre nem de reumatismo nem do nervo ciático ou de outros males do gênero, atribuirá à água sulfurosa pouco mais do que um interesse científico.

Isto me ficou muito claro durante o almoço no estabelecimento de Ohland. Na minha frente sentava um velho italiano de Guaporé. Visitava os numerosos filhos que moravam na margem esquerda do Chapecó. Quanto soube ele não tomava nunca água sulfurosa.

No meu ao lado sentava Haubert em companhia de um advogado judeu de barba ruiva e nome eslavo. Pronunciava de forma estranha o " $m$ " final dos verbos em português. Era incapaz de nasalá-los. Os dois bebericavam água sulfurosa como quem não tem nada melhor à disposição. A meu lado sentava Schickling emborcando um copo depois do outro. "Bajuware" nenhum toma a cerveja assim, acompanhada com queijo e rabanete.

Eu estava com meu primeiro copo e, compreensivo, observava Schikling. Eu sabia que ele contraíra tamanho problema no ciático durante as medições de terra durante o último ano, que não conseguia nem ficar em pé, nem caminhar, nem deitado e que as águas de "Mel", em questão de um mês, o haviam restabelecido completamente. Compreendi então o significado dado à expressão “Águas de Mel”, em presença de cujo odor a pessoa sadia torce o nariz e ins- 
tintivamente fala baixinho: que horror, pfui, ovos podres!

Pelas três horas Schickling esvaziou o último copo (depois do almoço o dono da estalagem buscara um novo garrafão) e nos pusemos a trotar morro acima. Como a nova estrada que corta a área de Culmey e deverá conectar com Passo Fundo, via Faxinal do Tigre, Passo dos Índios, Goio En e Nonoai ainda não fora entregue, começou a nova escalada nas encostas de Chapecó, passando por cima do dorso até Lajeado Bonito e, de Lajeado Bonito, por cima do morro até Dom José e mais adiante. Aos poucos se impõe uma mudança na paisagem e na agricultura. Já não se veem vales na forma de panelões. Os cursos de água cavam seus leitos em vales estreitos. A composição da vegetação oferece todos os representantes da mata do Uruguai, mas a altura diminui e os pinheiros tornam-se mais freqüentes. Ao longo do caminho o mato foi derrubado. Mas no lugar de plantações de mandioca da Linha Fortaleza, em Porto Novo, vicejam os inevitáveis "franceses" nas clareiras. Em vez dos galpões abarrotados de tabaco da Linha Laranjeira, sobressaem cabanas em ruínas em meio a pomares de laranjeiras em vias de serem tomadas pelo mato. Em vez das casas asseadas de Cotovelo, podem-se ver, ainda, alguns ranchos.

Não há nada mais desolador do que um assentamento abandonado na mata virgem: o mato devastado, as últimas plantações afogadas na vegetação, as casas e ruínas. Não sei por que razões a população aqui fixada mudou-se para outros lugares. Pela primeira vez me veio o pensamento que nos dias seguintes se confirmou plenamente: No Chapecó termina o mundo!

Escurecia quando nos aproximamos de Caxambu e apeamos na moradia de um italiano. Ele tocava o pequeno negócio. Quando acontece que aparecem hóspedes naquela região retirada, na qual há cinco anos não entram povoadores, seu negócio serve também como hospedaria. Não demorou que o escrivão do povoado se apresentasse. Era um antigo seminarista que aproveitou a ocasião para informar- se sobre seus camaradas de escola há muito tempo ordenados.

Juntou-se mais um ao grupo. Experimentei o mais franco prazer com ele. Era um homenzinho de crânio comprido, com incidência de traços indígenas, tratado pelos outros como Senhor Lara. Calçava perneiras, vestia calça cinza e casaco azul. Tinha uma conversa agradável, desfazia-se em mesuras e sabia fazer interessante os assuntos tediosos. Tive que rir comigo mesmo quando Haubert, que o conhecia há mais tempo, pediu emprestado suas famosas montarias para o dia seguinte. Sem piscar os olhos veio com a resposta que um cavalo mancava, que um segundo fora prometido para um compadre e que o terceiro encontrava-se em viagem. $\mathrm{O}$ dono da estalagem, sempre com os cotovelos apoiados no balcão e sorrindo amavelmente para todos, contou apenas uma história, típica para o povoamento do sul do Brasil. Quando há alguns anos vinha do Rio Grande do Sul (é originário ainda da Itália), encontrou uma cabocla velhíssima morando na terra. Explicou-lhe que a terra era agora sua e apresentou as escrituras. A velha agarrou um porrete, plantou-se diante dele e gritou: Criei-me nas proximidades de Caxias (do Sul). Vieram os gringos e tiraramme a terra! Casei em Guaporé no Rio Grande do Sul. Os gringos me seguiram e me tomaram a terra. Refugiei-me, então, no outro lado do Uruguai e também aqui chegam os malditos e perturbam a tranquiilidade dos meus velhos dias! Quero 400 mil réis contados por minha terra! O que poderia fazer. Paguei-lhe 400 mil réis e a velha foi morar em Iraí. "A mudança do brasileiro vai toda num cargueiro". ${ }^{46}$

Na manhã seguinte, quarta-feira 7 de março, procurei ter uma visão de conjunto sobre Caxambu. Não é tão fácil porque o povoado consiste essencialmente numa enorme "praça", plantada com mata-pasto e no centro uma figueira-do-mato. Quando se vai debaixo daquela árvore e se pega o binóculo, enxerga-se ao

\footnotetext{
${ }^{46}$ Por cargueiro, entende-se, aqui, um cavalo ou uma mula de carga (ABR).
} 
redor uma moldura de barracos baixos de madeira e, entre eles, sozinha na encosta do morro, a igrejinha que causa uma impressão agradável.

Atrás de Caxambu cavalga-se de novo por vales desolados e abandonados. Ao que tudo indica, a emigração ainda se encontra aqui em pleno andamento, pois em toda a parte o milho e a mandioca sobressaem ao mato. $\mathrm{O}$ milho cobria encostas inteiras e entrava no pendão quando os gafanhotos o devoraram e devastaram tudo, até sobrarem apenas os caules e as ripas das folhas. Estas plantações ressequidas dão a impressão de calamidade e, no meio delas, rodopiam nuvens de sementes de "franceses."

Pelo meio dia começou uma subida acentuada. O altímetro chega a 450 metros, o que nunca aconteceu em todo médio Uruguai. Os pinheiros dominam cada vez mais a paisagem, mas sempre associados a árvores comuns. Somente quando subimos o último vale e o altímetro marcou 500 metros, em menos de três quilômetros operou-se uma transformação na mata e na paisagem quase impensável. De um golpe desaparecem todos os representantes do assim chamado mato branco, para ceder lugar às cinco árvores características da Serra: timbó ${ }^{47}$, erva-mate $^{48}$, araucária ${ }^{49}$ e palmeira ${ }^{50}$.

Ainda hoje não sei explicar porque as duas zonas florestais contrastam tão fortemente. Só uma coisa é certa. Em toda a parte onde os derramamentos formam um altiplano contínuo e suavemente ondulado domina o campo. Onde vales em forma de panelão os interrompem predomina a mata virgem. É possível que venha daí que as camadas superiores são de basalto.

\footnotetext{
${ }^{47}$ Ateleia glazioviana Baill. (Fabaceae), árvore pioneira da orla de capões-de-mato (JNCM).

${ }^{48}$ Ilex paraguariensis A. St.-Hil. (Aquifoliaceae), espécie nativa desde a Bolívia e Mato Grosso até o norte do Uruguai (JNCM).

${ }^{49}$ Araucaria angustifolia (Bertol.) Kuntze (Araucariaceae), o popular pinheiro-brasileiro ou pinheiro-do-Paraná (JNCM).

${ }^{50}$ Syagrus romanzoffiana (Cham.) Glassman (Arecaceae), o popular coqueiro ou gerivá (JNCM).
}

Sua decomposição parece resultar no solo vermelho do campo, enquanto nas áreas de fendas e fraturas a decomposição chega até as camadas mais profundas de "amgidalitos", cuja presença condiciona toda a agricultura do sul do Brasil.

Faxinal do Tigre consiste numa única estrada, bem acabada e levemente abaulada no meio, passando por algumas casas. Uma delas provavelmente a escola, pois nela havia muitas crianças. Todas esticaram o pescoço para olhar pelas duas janelas. Na outra estava em pé o mestreescola com as mãos nas costas.

Pelas duas horas da tarde saímos de um mato de pinheiros e estávamos no destino da viagem: Passo do Tigre, a capital do grande município de Chapecó, de 14.000 quilômetros quadrados. Numa depressão rasa, pela qual corre um arroio sobre lajes de basalto (por isso os arroios são chamados nesta região de "lajeados" ou "lajeadinhos"), cruzam-se duas estradas. Uma sobe a encosta do outro lado e deixa à esquerda a igreja e os prédios administrativos. A outra cruza o vale pela diagonal e leva ao hotel Paveretto, o melhor da localidade. Indicaramme um quarto com vista sobre a cidade, no qual, ao concluir pelos jornais espalhados por aí, alojara-se o sr. Berthier, atual prefeito de Passo Fundo.

Depois de uma cavalgada de três dias e meio, um pequeno descanso vem bem. Só nos encontramos de novo na hora da janta, enquanto uma grande movimentação tomou conta do hotel. É óbvio que não demorasse muito para que todos os funcionários estivessem a par de que o escrivão de Porto Novo se achava presente e alegrarem-se pelas muitas escrituras de terra que seriam exaradas. E, de fato, não eram todos águias que se reuniram em volta das bruacas do escrivão de Porto Novo. Um deles, que os demais chamavam de "Zeca", foi de imediato traído pelo sotaque italiano. Vestia um casaco com duas aberturas nas mangas, uma para a mão e a outra para o cotovelo e berrava de pura empolgação. Mas quando Haubert explicou que desta vez só trazia 19 escrituras de terra, as ca- 
ras ficaram compridas e a conversa de "fortissimo" caiu para "piano".

Foi bom assim, porque só desta maneira chegou a vez de um senhor que, num silêncio educado, bebericava seu vinho. Tratava-se de uma pessoa jovem e elegante, a quem chamavam de doutor, flexível como uma vara, um enorme nariz adunco num rosto amarelado e a barba rala. As botinas e o casaco azul algum dia devem ter sido elegantes, mas agora exibiam as marcas da mata virgem. Este jovem doutor viera do Rio de Janeiro, enviado pelo governo federal para demarcar uma área de terras para os índios entre Chapecó e Chapecozinho, a fim de garantir tranquiilidade aos semi-selvagens, na sua permanente fuga ante o avanço da colonização.

Falou poucas palavras conosco. Não foi possível concluir se foi por cansaço ou por consciência de classe. Observando-o ao lado de Schickling, o veterano da mata virgem, sentiase a vontade de resumir a expressão do seu rosto na seguinte fórmula: "Que o diabo carregue as medições no mato! Nas aulas práticas das escolas de agricultura as coisas parecem bem mais bonitas!".

Na quinta-feira de manhã minha intenção foi, na verdade, de viajar num caminhão de carga a Goio-En, no Uruguai. Mas a mulher do artista barbeiro explicou, lamentando, que o ofício principal do marido era de marceneiro e que, por motivo de negócios, não se encontrava.

Não foi bom, mas nem de longe tão ruim como o que aconteceu com o acompanhante do "doutor" do Rio de Janeiro. Ele arrumara uma forte dor de dente no mato e, encostado na entrada da porta, suava por debaixo do pano amarrado no queixo, embora fosse uma manhã amena. Nós o aconselhamos a procurar um dentista. Só voltou perto do meio dia e suava ainda mais do que pela manhã. Perguntamos, solidários, se tinha encontrado o dentista. "Não, mas o veterinário", falou baixinho, "e ele arrancoume o dente".

Na conversa com os funcionários, todos sem exceção do Rio Grande do Sul, logo pude concluir que desejavam que Passo dos Índios fosse parar na lua. Preferiam dedicar-se à sua função nas localidades mais progressistas do município, como, por exemplo, Palmitos ou Porto Feliz. O progresso transitório da região colonizada além de Nonoai, entre Irany e Chapecó, cedeu pouco a pouco lugar à decadência. Somente no rio do Peixe estaria acontecendo alguma coisa.

De um momento para outro ficou claro para mim que Santa Catarina, a oeste do Rio do Peixe (municípios de Chapecó e Cruzeiro, com 22.000 quilômetros quadrados), estava a caminho de tornar-se território riograndense. O notável é que esta região combina com o Rio Grande do Sul, também sob o ponto de vista geológico e da flora, enquanto a parte central do estado, com seu terreno magro formado por xistos e a leste com seu granito, nunca irão atrair colonos do Rio Grande do Sul.

Satisfeitos que Haubert tivesse resolvido tão rapidamente os negócios, deixamos Passo dos Índios no dia nove de março. O sol acabara de nascer e seus raios em feixes iluminavam as copas dos pinheiros.

Um pouco antes de Faxinal encontramos um papel dobrado na estrada. Schickling apeou e o desdobrou. "Versos!", riu e deixou-o cair no chão. Depois de vinte minutos aproximou-se, trotando, um senhor jovem e perguntou, entristecido, se não tínhamos visto seus versos na estrada. Sim, em tal e tal lugar. O poeta chicoteou o animal e saiu em disparada. Só Deus sabe o que lhe custaram os versos!

Pouco depois de Faxinal encontramos uma porteira de potreiro com uma cruz recente de madeira. Um pedestre que alcançamos pouco adiante contou que há duas semanas um comerciante fora encontrado enforcado no mato. Na guaiaca havia 250 mil réis. Para mim parecia quase simbólico que este comerciante falido e decaído de Nonoai tivesse que vir a esta região erma para por fim ao seu desespero.

O calor queimava para valer sobre as nossas costas ao descermos o vale do Lambedor. Aí encontramos, ao lado do caminho, o acampamento dos construtores da estrada. Implantava 
a conexão entre São Carlos e Passo dos Índios. O Sr. Stolz, agrimensor-chefe, conhecido de Schickling, estava sentado na frente da barraca, sobre a caixa do teodolito, tomando chimarrão.

Acomodamo-nos por meia hora na sua frente sobre o tronco de uma árvore e conversamos. Tratava-se de um homem de estatura mediana e cabelo louro-escuro, pele queimada pelo sol e, sobretudo, com aquele olhar singular que se poderia chamar de olhar de agrimensor, assim como há um olhar de motorista e um olhar de aviador. Por 13 anos este herdeiro de 300 "Morgen" ${ }^{51}$ de terra na Prússia Oriental cruzava a mata virgem. Espantoso era o número de mantas de toucicnho que impediam a vista para dentro da sua barraca de cozinha, aberta nos dois lados.

Saímos tão tarde de Caxambu que a noite nos surpreendeu uma hora antes de chegarmos a Chapecó. Foi uma cavalgada difícil, ladeira abaixo até o rio. Ficamos roucos de tanto gritar, antes que os filhos do Vitório aparecessem no outro lado e remassem lentamente até nós. Foi a primeira das três travessias do rio na escuridão da noite. Na linha do horizonte em redor, especialmente no ponto da queda abrupta da calha do Chapecó, subiam as trovoadas iluminando a noite.

Chegados ao topo, as luzes de São Carlos brilhavam na nossa frente. $\mathrm{O}$ sino ecoava pela noite, chamando para a Via Sacra. Ao passarmos o arroio ecoou da igreja iluminada o canto:

"Oh cruz santa, na qual pendeu meu Senhor, em grande angústia mortal."

$\mathrm{E}$, ao apearmos na frente do estabelecimento de Sander, o vento vindo da igreja, carregava os sons confusos:

"Verdadeira árvore da vida, na qual meu Deus a sua vida por nós sacrificou."

51 "Morgen" era uma antiga medida de superfície, variável nas diversas províncias. Na Prússia, correspondia a 25,532 acres; na Baviera 34, 073 acres; em Würtemberg 31,517 acres; na Saxônia 27,671 acres; na Badênia 36 acres; no Hessen 25 acres (ABR).
"Mel" foi o destino da viagem do dia seguinte. Evitamos o desvio por Palmitos, 20 quilômetros mais longe, e cavalgamos o dia todo por uma trilha no mato, entre o Uruguai e a encosta íngreme. Veio a ser a mais bela cavalgada de toda a viagem.

Começou com a passagem pela Barra Funda. Trata-se de um arroio do tamanho do Maca$\mathrm{co}$, um pouco mais estreito, sem barqueiro e sem canoa. O local da travessia encontra-se perto do Uruguai, no ponto em que suas águas se encontram com as do afluente, formando uma crista de onda que se prolonga até a margem oposta, no local exato onde a trilha continua mato adentro.

Informaram-me que bastava chamar com insistência e os caboclos que moravam mais acima viriam em socorro. Começamos a gritar com toda a força. Haubert estava quase rouco e lamentava os papéis que sofreriam danos, quando um cachorro latiu do outro lado. Um minuto mais tarde saiu do mato, acocorou-se, abanou o rabo, rosnou, latiu e uivou alternadamente, em nossa direção. Escutou-se depois uma batida de remo no Barra e uma canoa escavada de um tronco saiu flechando de dentro dos arbustos. Nela estavam em pé mais três cachorros e dois rapazes equipados para a caça. A travessia aconteceu com incrível tranqüilidade. Embarquei como último na canoa, porque pretendia observar os cachorros.

Almoçamos nas fontes sulfurosas da Ilha Redonda, que brotam com uma temperatura de 38 graus, imediatamente junto ao Uruguai, sendo as mais quentes de toda a região. Encontrase aí uma grande hospedaria, mas tudo é mantido numa simplicidade tal, que mesmo as pessoas modestas têm condições de se livrar do reumatismo sem uma sangria exagerada do bolso.

A viagem seguiu a tarde inteira, trilha mais trilha e só trilha, à esquerda o rio, à direita a encosta íngreme, acima de nós a mata e, em ambos os lados, folhas novas de samambaia. Se uma trilha de 100 quilômetros cruzasse a mata virgem do Uruguai e fosse preciso cavalgar durante 20 dias, lamentaria quando a viagem ti- 
vesse acabado. Se crescessem apenas leques de samambaias na margem da trilha, se apenas as aranhas tecessem suas redes circulares por sobre a trilha e as raízes de guaimbé pendessem do alto e o Uruguai não se esquecesse de entoar sua canção, levaria um bom tempo para o tédio tomar conta da gente em meio a esta natureza de Deus.

Só pelas nove horas passamos por Passarinhos e chegamos ao rio. Apanhamos a balsa no último momento. Acima, à esquerda, erguia-se contra o céu a vila de Culmey, imitando um castelo. O horizonte inteiro ardia em raios. Após meia hora no lado riograndense topamos com o rio Mel. Passa-se por ele também numa balsa, embora seja tão estreito que ela quase toca nas duas margens.

$\mathrm{Em} \mathrm{Mel}{ }^{52}$ pernoitamos numa pequena hospedaria e, na manhã seguinte, pusemo-nos o mais cedo possível a caminho, para continuar a viagem. Este balneário moderno, com seus vadios ilustres sentados na frente de todas as hospedarias, não me interessa nem um pouco. Antes de passarmos por cima do morro, convencime, mais uma vez, de que a cidadezinha de Mel se localiza num típico vale em forma de panela. As fontes vindas das profundezas da terra sobem por cilindros de cimento.

Até às quatro horas da tarde cavalgamos por trilhas no mato. A região é esparsamente povoada, predominando os italianos. É flagrante a falta de planejamento e visível a decadência.

Seguindo pela estrada alcançamos, ao por do sol, o ponto mais alto da calha do Uruguai, descortinando uma visão única sobre o mar que ondula tranquiilo, formado pelo mato que cobre os morros. Na entrada da noite acenderam-se, lá em baixo, as luzes de Porto Feliz. O relógio marcava oito e meia ao alcançamos o rio. Depois de passar pela estrada que passa sob a vegetação densa subimos na balsa pela terceira vez naquele dia.

No dia seguinte, de manhã, segunda feira, 12 de março, a chuva impediu a continuação da

\footnotetext{
${ }^{52}$ Atual Irai (JNCM).
}

viagem. Partimos só depois do meio dia. No arroio Taipa desabou sobre nós uma pesada trovada, dificultando sobremodo a cavalgada através dos "franceses." E, quando perto do por do sol chegamos ao arroio Catres e com ele à boa estrada de Porto Novo, ficou de um lado a convicção que o mundo termina no Chapecó e, do outro, que do Chapecó ao Peperi não existe outra colônia que, apesar de tudo, mostra tanto progresso como Porto Novo.

Na terça feira de manhã Rohde deu uma chegada rápida até Itapiranga. Nossa intenção foi passar o rio pelo meio dia para, à noite, estarmos em Palmeira (das Missões) e, na manhã seguinte, viajarmos de trem a Santa Bárbara. Tudo fora bem planejado, mas não havíamos contado com o fator tempo.

Já durante a manhã toda o sol era de um amarelo estranho e no ar pairava uma atmosfera sufocante. Pelo meio dia começaram a crescer atrás do mato, árvores brancas do tempo. Armaram-se numa grande frente e aproximaram-se bramindo. Acabáramos de nos servir de sopa quando, repentinamente, o temporal se desencadeou. Primeiro o farfalhar de folhas das bananeiras na frente da casa, depois o estalar das folhas de zinco no telhado e por fim um redemoinhar, um barulhar e um troar no ar, como nunca, nunca havia presenciado na minha vida.

Parecia que os espíritos da tempestade estavam pousados sobre as abas do telhado e tentavam derrubá-las com as loucas chicotadas das suas asas e arrancar os muros dos seus fundamentos. A lâmpada sobre a mesa tremia ao uivo de cada lufada e as cadeiras se deslocavam conosco sobre o assoalho. Como que despejada com baldes, a água escorria pelas janelas e em torrentes escoava por entre os batentes.

Sentados junto à sopa a cada golpe imaginamos: agora a casa se desfaz em pedaços, ainda mais quando, pelo final, pedras de granizo começaram a martelar contra as vidraças. Então, num golpe, a tempestade amainou e se afastou, com a mesma rapidez que viera.

O Sr. Rohde precipitou-se para fora, porque os dois filhos maiores, um menino e uma meni- 
na, voltavam da escola e estavam a caminho no momento da tempestade. Não demorou a aparecerem, os sapatos perdidos, as mantas enroladas na cabeça, duros de imundície como se fossem ídolos de barro. A tempestade os apanhara de repente lá em baixo, no canavial. Deitaramse no chão e seguraram-se na cana e o vento os rodopiou como uma peça de roupa no varal. Além disto, nada sofreram.

Mais feio foi rio Uruguai acima, onde pés de mandioca da altura de um homem foram arrancados com as raízes e jogados a esmo. Soubemos logo em seguida que na entrada da Linha Chapecó a casa do alemão Hövel fora derrubada. Fomos até lá. Nunca teria imaginado que, em três minutos, um ciclone fosse capaz de provocar tamanha devastação. Na encosta do morro jaziam grapiapunhas e angicos torcidos, quebrados, atirados uns sobre os outros, obstruindo parcialmente a estrada. Até a taquarinha do mato estava amassada como se cavalos tivessem rolado sobre ela.

Os Hövel almoçavam quando tudo começou. Primeiro desabaram as árvores em volta, depois os pratos e as bacias voaram para debaixo da mesa e, por fim, a casa arriou dos postes e caiu perigosamente entre eles. A estrebaria, com vaca e cavalo, foi sepultada debaixo de um angico. Os dois animais apoiados nos joelhos foram retirados com a ajuda do machado. Um terneiro preso debaixo da casa salvou-se a tempo. Pereceu apenas um porco e uma choca.

Quando cheguei acabavam de acomodar o trem de cozinha debaixo de uma barraca de lona improvisada. A mulher estava sentada aí com duas crianças, rodeada da maior confusão de utensílios de cozinha e peças de roupa, enquanto no sótão, o homem, um engenheiro do sul da Alemanha, tratava de por em seguro as folhas de tabaco que lá secavam.

Levamos as crianças, duas meninas, conosco. Rohde mandou que o peão e seu marceneiro ficassem para auxiliar na reconstrução. Ficou evidente a lamentável constatação que os vizinhos mais próximos, a quem o vento arrancara só poucas tabuinhas do telhado, pouco se im- portaram com a desgraça dos Hövel. Há pouco vi no "Volksblatt" 53 a casa reconstruída.

Neste meio tempo escureceu e não foi mais possível viajar naquele dia. No dia seguinte, na mesma hora, estávamos sentados em Santa Bárbara. Rohde sabia o quanto me agradavam as histórias dos tesouros dos jesuítas que circulam aqui em quantidade. Chamou para a nossa mesa um senhor baixinho e redondo, tirou a rolha de uma garrafa de vinho e encaminhou a conversa na direção certa.

O nosso novo conhecido era um suíço nato e, certamente, nenhum daqueles a ponto de morrer de fome. Carregava no sangue a inquietude dos caçadores de tesouros. Encaroume com seus olhos grandes e faiscantes e, com voz comedida, falou durante uma hora e meia. Reproduzo em resumo uma das suas histórias.

Um certo padre (Deus sabe que padre era) visitou um fazendeiro e, no meio da conversa, como quem não quer nada, perguntou por uma palmeira com três copas, que estaria em algum ponto da fazenda. O fazendeiro conhecia a palmeira. "Cheira a assado", concluiu, e mentiu dizendo que não sabia de nada. Mas o padre se afastou e o fazendeiro reuniu a toque de caixa os peões e, durante duas semanas, cavou o chão em volta da palmeira, até uma profundidade de três metros. Ele, o suíço, chegou a saber da coisa, empreitou homens e cavou num outro local com as mesmas características. Passou uma semana e estavam a ponto de desanimar. Então, a dois metros de profundidade, toparam com um punhal e um tinteiro. Obviamente os dois apontavam na direção dos jesuítas. Nestas circuns-

\footnotetext{
53 "Volksblatt", cujo nome completo era "Deutsches Volksblatt" foi o jornal teuto-católico publicado a partir de 1872, primeiro pelos jesuítas, em São Leopoldo, e depois por Hugo Metzler e seus filhos, na Tipografia do Centro, em Porto Alegre. Sua circulação foi proibida na Campanha de Nacionalização, em fins da década de 1930. Uma coleção incompleta se encontra no Memorial Jesuíta, na Biblioteca Central da Universidade do Vale do Rio dos Sinos. Trata-se de fonte obrigatória, ao lado do jornal teuto-protestante "Die Post" e do jornal teuto-liberal "Deutsche Zeitung", para os que pretendem estudar a história da imigração alemã no sul do Brasil (ABR).
} 
tâncias um cabo de colher ou uma peça de artilharia teriam provado o mesmo. Cavaram mais duas semanas como selvagens, são assaltados por um outro bando armado, entendem-se e, juntos, continuam cavando, sem encontrar nada. - "Porque o senhor se mete nisto, quando tantas vezes já perdeu seu tempo e, além disto, os tesouros não lhe fazem falta?" - Por diversão, respondeu o suíço. Parecia-me, contudo, que a fantasia do homem se incendiava na medida em que eu me interessava. Os dois insistiram que na manhã seguinte me levariam, 25 quilômetros campo adentro, para ver "in loco." Lembrei-me que naquele horário deveria estar em São Leopoldo, assistindo à "Lectio Brevis" (breve conferência introdutória) e resisti.

Lamentei especialmente porque os dois afirmaram que, em duas semanas, todos os fazendeiros da região seriam acometidos pela febre do ouro, logo que se tornasse público que um padre estivera na cova do tesouro.

Pouco antes da partida, na manhã seguinte, o suíço apresentou-me um fazendeiro e disse baixinho: "Observe-o. Já foi rico, mas malbaratou todo o dinheiro com automóveis e seria o primeiro a aparecer com a pá na mão, na cova do tesouro.

Apertei a mão do homem franzino de botinas altas, o cabelo castanho penteado para trás e o rosto com traços fortes, a cuja provocação magnânima devo o maior êxito da minha viagem e, sonhando, atravessei o interminável campo. O sol forçou a passagem pelas nuvens e invadiu a atmosfera e a terra com seus raios de um amarelo singular, mesclados com vapor de água, prenúncio de chuva. Ondas de colinas e mais ondas de colinas, cobertas com capim raso e semeadas com milhares de compostas, vermelhas e amarelas, ondulam como as ondas do mar, em todas as direções. Refluem e formam uma linha divisória nítida entre o céu e a terra. Manadas de reses, ora com um vermelho-castanho uniforme, ora malhados em preto e branco, pastavam dispersas nas ladeiras das coxilhas. Uma tropa de cavalos semi-selvagens galopava pelo campo diante da locomotiva, soprando pelas ventas, a cabeça projetada para frente, as colas e as crinas esvoaçando ao vento. Burros e mulas permanecem onde estão e encaram o trem com um olhar impossível de se saber se se trata de burrice impotente ou astúcia calculada. Entre eles movimenta-se um bando de emas, bicando os besouros nas flores e banham-se no "Kohlentau" ao lado da estação.

Tenho a impressão que, quando se observa durante tempo suficiente o campo, descobre-se nele a grandeza e a beleza, comparável à floresta virgem, às altas montanhas e ao oceano.

Depois começou a chover e a noite baixava sobre a planície do Jacuí, enquanto sentado no vagão a gente se esforça para não pensar em nada, meio dormindo, meio acordado. A história do punhal e do tinteiro dos tesouros dos jesuítas girava como uma roda de moinho na minha cabeça. De vez em quando se intrometia no meio a manifestação de um colono de Porto Novo: "Se ele merece o céu coletando plantas eu o mereço bebendo cachaça".

Da neblina da manhã emergiram as torres e as chaminés da cidade no Sinos (São Leopoldo) e conclui que a viagem para a terra do futuro estava definitivamente terminada. 